Historic, Archive Document

Do not assume content reflects current scientific knowledge, policies, or practices. 

$50^{\prime \prime}$

42

\section{Lil M/s}

Choosing an Activity Fuel Treatment for Southwest Ponderosa Pine and David L. Radloff
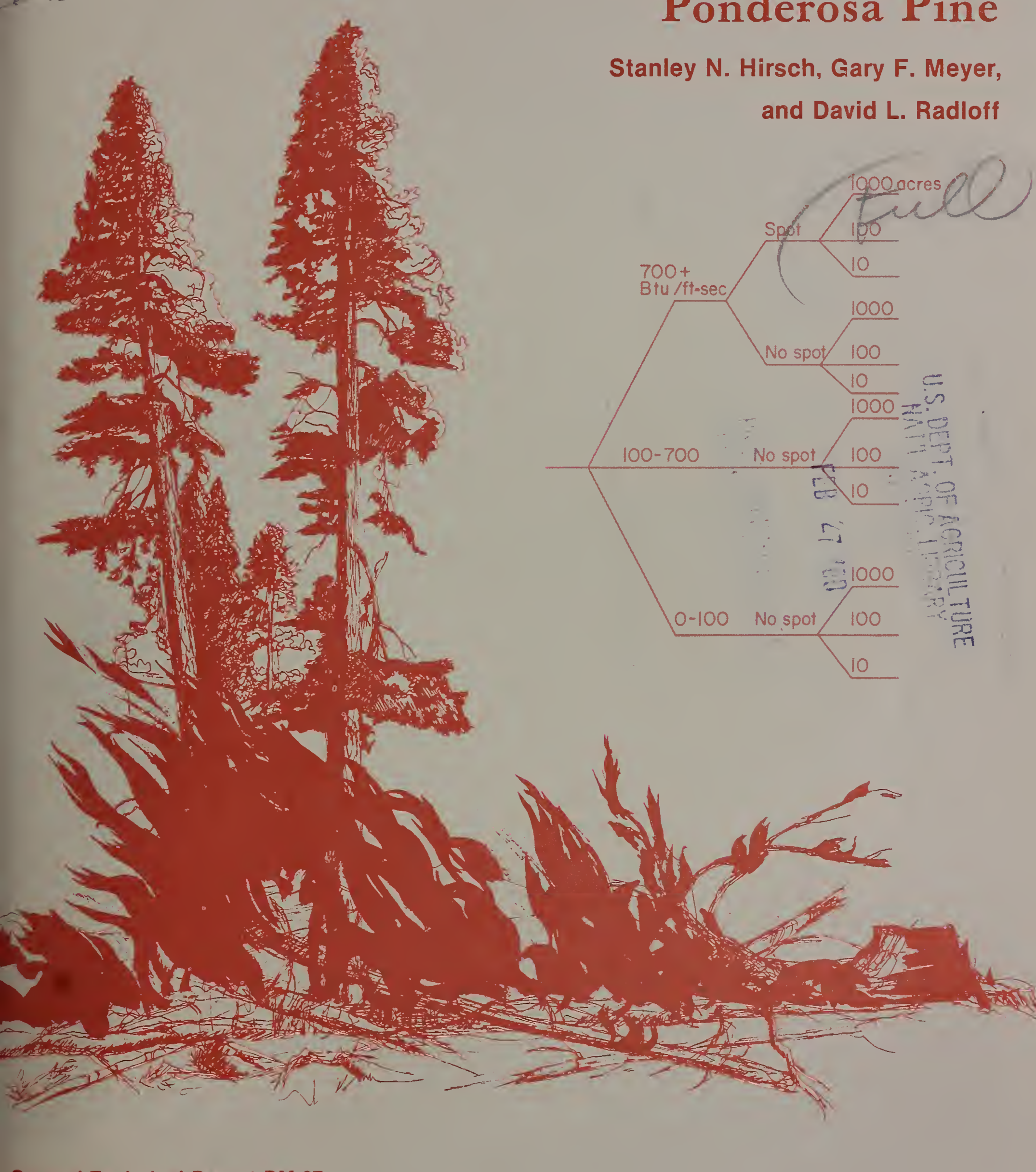

General Technical Report RM-67

Rocky Mountain Forest and

Range Experiment Station

Forest Service

U.S. Department of Agriculture 


\title{
Choosing An Activity Fuel Treatment for Southwest Ponderosa Pine
}

\author{
Stanley N. Hirsch, Engineer, ${ }^{1}$ \\ Gary F. Meyer, Forester, ${ }^{2}$ \\ and \\ David L. Radloff, Research Forester ${ }^{1}$
}

\begin{abstract}
Fire hazard projections using decision analysis, fuelbed-, fire behavior-, and probability-modeling on the Coconino National Forest indicate that, considering only timber-related cash flows, piling and burning sawtimber slash is the preferred fuel treatment for southwest ponderosa pine, although this treatment also has the highest expected annual burned acreage.
\end{abstract}




\section{Choosing an Activity Fuel Treatment for Southwest Ponderosa Pine}

\section{Stanley N. Hirsch, Gary F. Meyer, and David L. Radloff}

The skyrocketing cost of wildfire-related activities is making wildland fuel management decisions increasingly important. Of particular concern is the fire hazard of residual debris from cutting operations. Accomplishing land management objectives may depend on treating large areas of such activity-fuel deposits using such tested treatments as fire, manual, or mechanical means to reduce fuel loadings.

The National Fuel Inventory and Appraisal Project has developed a general approach for evaluating fuel treatments. The approach combines state-of-the-art fuelbed-, fire behavior-, and probability-modeling in a decision analysis framework. ${ }^{3}$ To test this method, a case study was conducted on the Woods Canyon Watershed, Mormon Lake Ranger District, Coconino National Forest (fig. 1). This paper discusses the fuel appraisal methods employed and the results obtained for fuel treatments proposed by forest personnel.

\section{Study Area}

The Woods Canyon Watershed contains about 12,000 acres of ponderosa pine forest-a mosaic of small, even-aged "stands" ranging from stagnated saplings to mature sawtimber (Ffolliott et al. 1968). Most of the even-aged patches are smaller than 1 acre. Surface fuels show a similar lack of uniformity. Average fuel loads in the area are light, but concentrations of heavy fuel exist which greatly influence fire behavior. The nonuniformity of forest cover and dead fuels presents special problems for fire hazard appraisal. The methodology discussed in this paper is designed for the heterogeneity typical of ponderosa pine forests.

\section{Problem}

The Coconino National Forest has a very high wildfire ignition rate. The Mormon Lake Ranger

${ }^{3}$ Hirsch, Stanley N., and David L. Radloff. A method for analyzing activity fuel decisions. U.S. Dep. Agric., For. Serv., Rocky Mt. For. and Range Exp. Stn., Fort Collins, Colo. (in preparation).
District alone experiences about 98 fires per year, or 1 fire for every 3,500 protected acres. A very effective fire suppression organization has kept most of these fires small. An unfortunate result of such effective fire suppression is an increase in dead fuel over large areas. Prior to the establishment of fire protection, repeated surface fires maintained natural fuels at lower levels and thinned dense pine reproduction. ${ }^{4}$

The addition of activity fuel (fuels created by man's activities) to these natural fuels is a major concern of local forest managers. Sawtimber harvesting, pulpwood harvesting, and precommercial thinning are planned for the entire Woods Canyon area and will add to existing fuel loads and increase fire hazard. Forest managers are considering five alternative fuel treatments to mitigate these effects:

1. Pile and burn sawtimber slash. (The local, very heavy slash concentrations from single-tree sawlog harvesting are not acceptable to area managers. These present high hazards immediately and result in jackpots which may persist for several decades. Because of this, piling and burning sawtimber slash is considered a minimum fuel treatment.)

2. Pile and burn sawtimber and thinning slash.

3. Broadcast burn the entire area by prescription prior to thinning.

4. Broadcast burn and use the burning to accomplish thinning.

5. Develop "clean" corridors and fuelbreaks to limit the size of escaped fires. (We did not formally analyze fuelbreaks as an alternative to direct fuel treatment. Unless fuelbreaks are very wide, they will not stop crown fires, nor will they prevent long-range spotting from propagating fire spread. In areas where access is poor, fuelbreaks may be effective in permitting quicker attack on fires.)

The important question is "What fuel treatment(s) will have the greatest net benefit?" The results of our analysis of acres expected to be burned by wildfire dur-

'Dieterich, John H. 1976. Prescribed burning in ponderosa pine-State of the art. $18 \mathrm{p}$. Paper presented at Eastside prescribed burning workshop [Bend, Oreg., May 3-7, 1976]. U.S. Dep. Agric., For. Serv., Pac. Northwest Reg., Portland, Oreg. 
ing the next 21 years and present net worth of fire- and timber-related cash flows for the entire Woods Canyon sale area under four management alternatives are shown below. (Since clear guidelines are not available concerning the most appropriate interest rate for forest management investments, a $5 \%$ interest rate was used. The effects of different interest rates are discussed in a later section of this paper.)

\section{Expected acres Present net burned worth $(5 \%$ by wildfire interest rate)}

Pile and burn saw-

$$
\text { timber slash }
$$$$
1,126 \quad \$ 2.1 \text { million }
$$

Pile and burn sawtimber and thinning slash

\section{$\$ 2.0$ million}

Broadcast burn prior to cutting

Broadcast burn to thin

These results are discussed in detail below.

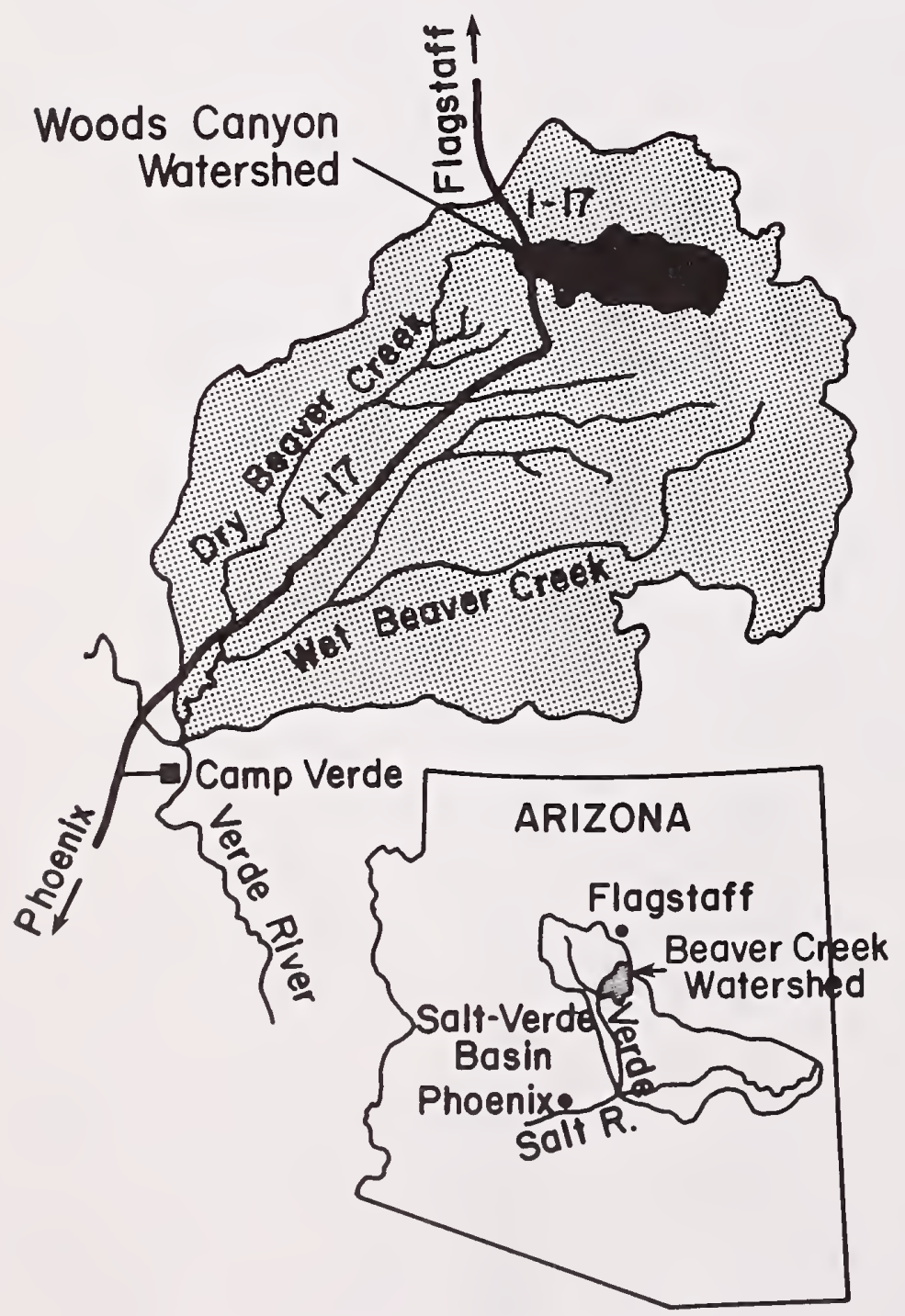

Figure 1.-Location of Woods Canyon Watershed (U.S. Department of Agriculture 1977).

\section{Solution Framework}

Evaluation of alternative treatment methods requires knowledge of how fire losses are affected by changing the fuel complex. In ponderosa pine relatively "cool" ground fires are easily suppressed and do litthe resource damage. Under present suppression policy only very hot fires escape attack and become large-often causing substantial damage. Therefore, fire size is a useful indicator of fire loss.

The procedure outlined in this paper estimates the probability a fire will exceed 10 acres for each fuel treatment alternative. Fires of less than 10 acres are considered small fires with little associated damage. Historical average size for fires larger than 10 acres (400 acres) is used to estimate the expected size if the 10 -acre size is exceeded.

\section{Large-Fire Process}

Most large fires in the Woods Canyon area are caused by long-range spotting. Interviews with local fire management officers and fire researchers indicated that litter fires are usually kept small unless they produce long-range spot fires (over 1/8 mile). The interviews also revealed that where slash is absent, the firebrands causing spotting usually come from dense patches of sapling trees (doghair) which torch out. These doghair clumps have low crown bases, so most fuel concentrations in excess of normal litter fuel (fuel particles less than 1 inch in diameter) will produce flame lengths sufficient to ignite the crowns. Thinning the doghair clumps reduces the chance of clumps torching out, but the thinning slash can produce firebrands which are lofted above the canopy, causing long-range spotting as did the doghair clumps.

\section{Spotting Model Before Cutting}

A precutting spotting model can be represented as a race between the spot fire production/growth rate and fire suppression forces. The model asks, "Does a surface fire cause a doghair clump to torch out before the fire can be extinguished?' 'The answer depends on the surface fire spread rate, the distribution of doghair clumps and jackpots (concentrations of medium to heavy fuels sufficient to cause torching in doghair clumps), the rate at which firebrands are produced, and the speed of suppression forces.

The model estimates the probability a fire will escape initial attack and produce spot fires under specified fuel and weather conditions. The model assumes a fire will become larger than 10 acres if a spot fire generates a second, independent spot fire. This is discussed in more detail in appendix 1. 
Additional assumptions concerning the spotting process are:

1. Long-range spot fires can be generated if the 10 -hour timelag fuel moisture is $\leqslant 10 \%$ and the windspeed is $\geqslant 10$ miles per hour. Under these weather conditions, a doghair clump which contains a burning jackpot will torch out.

2. An existing fire produces, at most, one new, independent, long-range spot fire.

3. Weather data collected at Pulliam Field near Flagstaff, Ariz., reflect weather conditions in Woods Canyon.

\section{Spotting Model After Logging}

The presence of numerous patches of thinning slash reduces the chance of suppressing ground fires. A fire no longer has to reach a point target (jackpot) to cause spotting; it has only to reach an area of thinning slash. Once the fire is into slash, there is little chance that it can be stopped until it burns through the entire patch. For thinning slash, the model assumes long-range spotting will occur if the 10 -hour moisture is $\leqslant 10 \%$, the windspeed is $\geqslant 10$ miles per hour, and the fire is burning with a fireline intensity of at least $700 \mathrm{Btu} / \mathrm{ft}-\mathrm{sec}$. Based on the distribution of the areas to be thinned and modeled fire growth rates, the estimated probability is 0.83 that any fire would reach thinning slash. The derivation of sequential spotting probabilities for the slash situations is discussed in appendix 1 .

\section{Evaluation Methods}

Evaluating a fuel treatment requires estimating the properties of the fuelbed it produces.

Prior to cutting, needle litter and woody fuels less than 1 inch in diameter are distributed rather uniformly over the entire area with concentrations of larger fuels locally superimposed on the fine particles.

Cutting superimposes a quantity of slash on the existing fuels. The amount and characteristics of activity fuels were estimated by procedures developed at the Northern Forest Fire Laboratory (Puckett et al. 1979; Brown et al. 1977; Albini and Brown 1978).

Prescribed burning prior to thinning reduces or eliminates some of the existing fuels. The effect on litter may be short-lived because of increased fall of scorched needles, but the effect on large fuels is longer lasting. A detailed description of each fuelbed used in this analysis is given in appendix 2.

For each fuelbed, Rothermel's (1972) fire spread model was used to estimate fire behavior over the

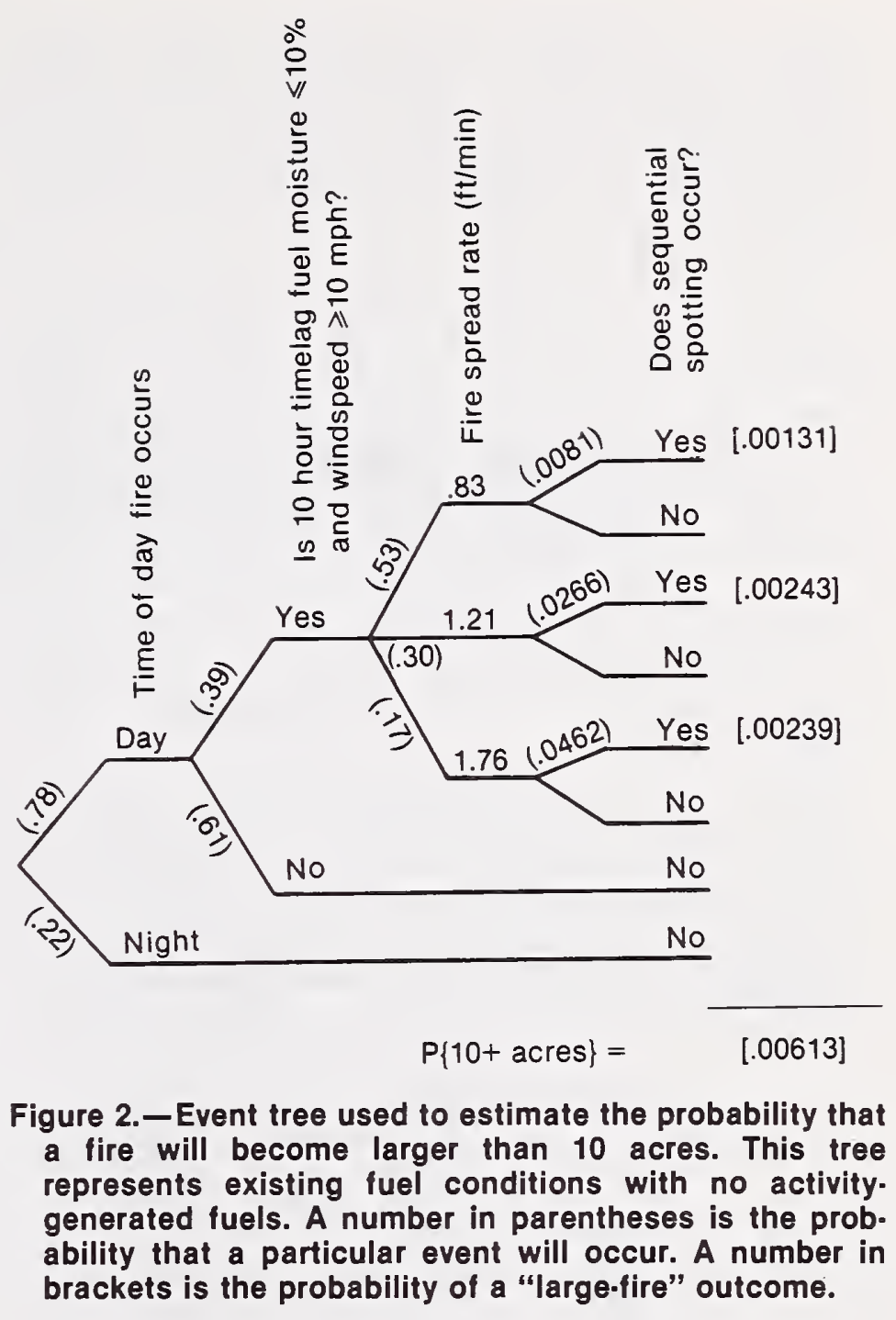

range of fuel moisture and windspeed conditions experienced at Flagstaff. The model predicts expected fire spread rates and intensities (app. 1). In order to reduce this information to a single fuel appraisal "index,' an event tree was formulated combining weather data, modeled fire behavior, and the large-fire spotting model. Evaluating the event tree yields the probability a fire will become larger than 10 acres.

Figure 2 illustrates the event tree for estimating large-fire probability prior to cutting. The first two nodes of the tree represent probabilities the specified weather conditions will be observed when a fire occurs. These probabilities were obtained from Flagstaff weather data (1970-76). The third node shows the probability a fire will spread at a particular rate. The last node shows the probability a fire will spot twice in sequence (or that a fire will be larger than 10 acres). The product of all probabilities along the path leading to a branch tip is the probability that outcome will occur. Summing for all the sequential spotting outcomes yields the probability that any fire will become larger than 10 acres.

The precutting event tree indicates a large-fire probability of 0.006 . Historically, the proportion of fires 
larger than 10 acres on the Mormon Lake Ranger District (which includes Woods Canyon) is 0.005 . This correspondence between the model and actual observations indicates an analogous model may be useful in evaluating activity fuels.

An event tree to estimate large-fire probability in the presence of activity fuels is shown in figure 3 . Nodes 1 and 2 concern weather criteria for spotting. The third and fourth nodes represent the distribution of sound or rotten jackpots. (For example, $70 \%$ of the Woods Canyon doghair clumps have an initial stocking of 1,000 stems per acre; of these, $40 \%$ can be expected to contain a sound-log jackpot.) The last node shows the probability that the fire will spot twice in sequence. In the example, the probability of a fire over 10 acres is 0.13 -more than 20 times the probability without slash.

The results from modeling the conditions prior to cutting, cutting with no fuel treatment, and broadcast burning prior to cutting are compared in figure 4 . These model results provide the information required to compare the effects of the various fuel treatments.

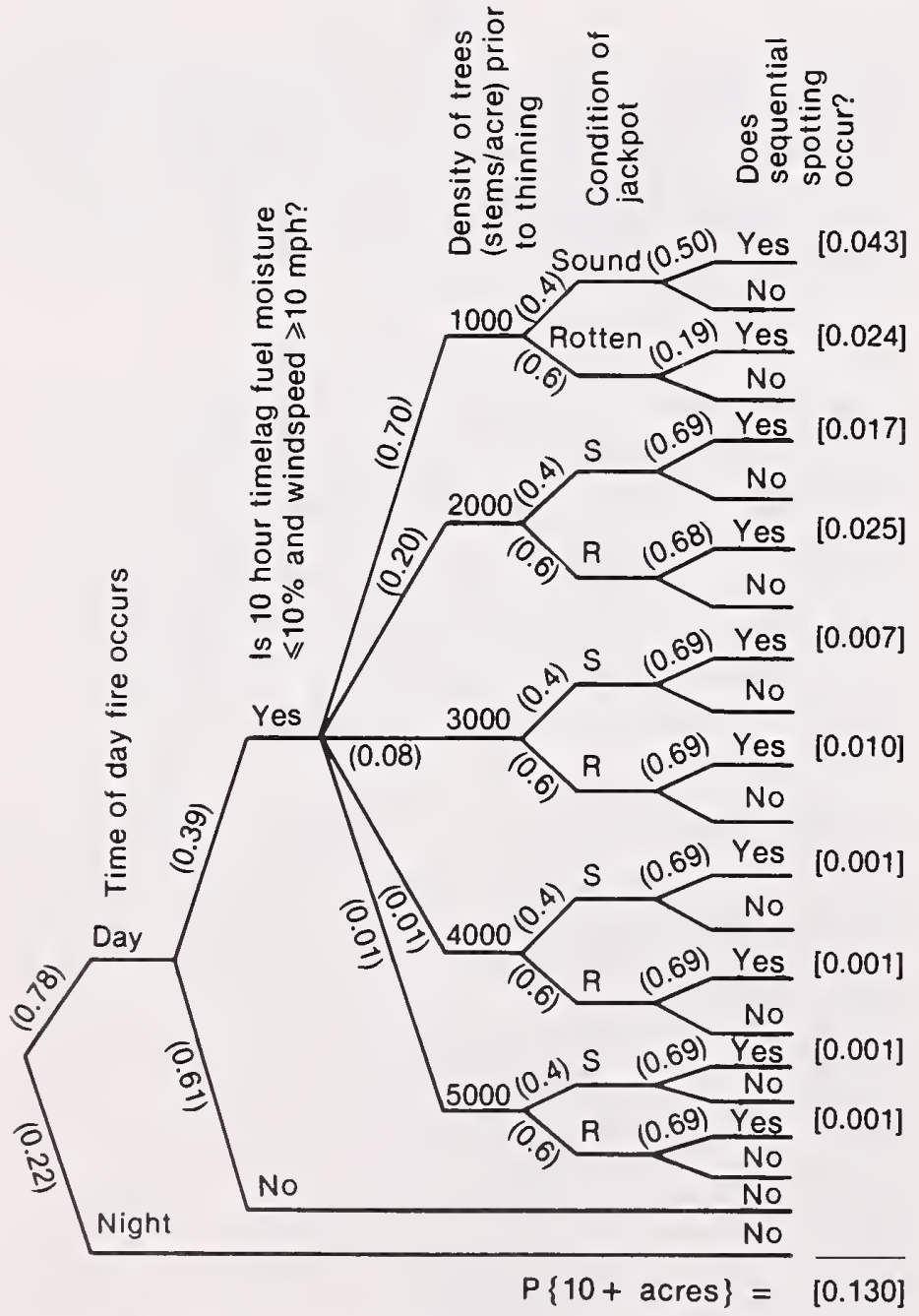

Figure 3.-Activity fuel decision tree to estimate the probability of occurrence of a fire larger than 10 acres. The fuelbed represented is untreated, 1-year-old thinning slash draped over large fuel concentrations. This tree represents the worst modeled fuel situation.

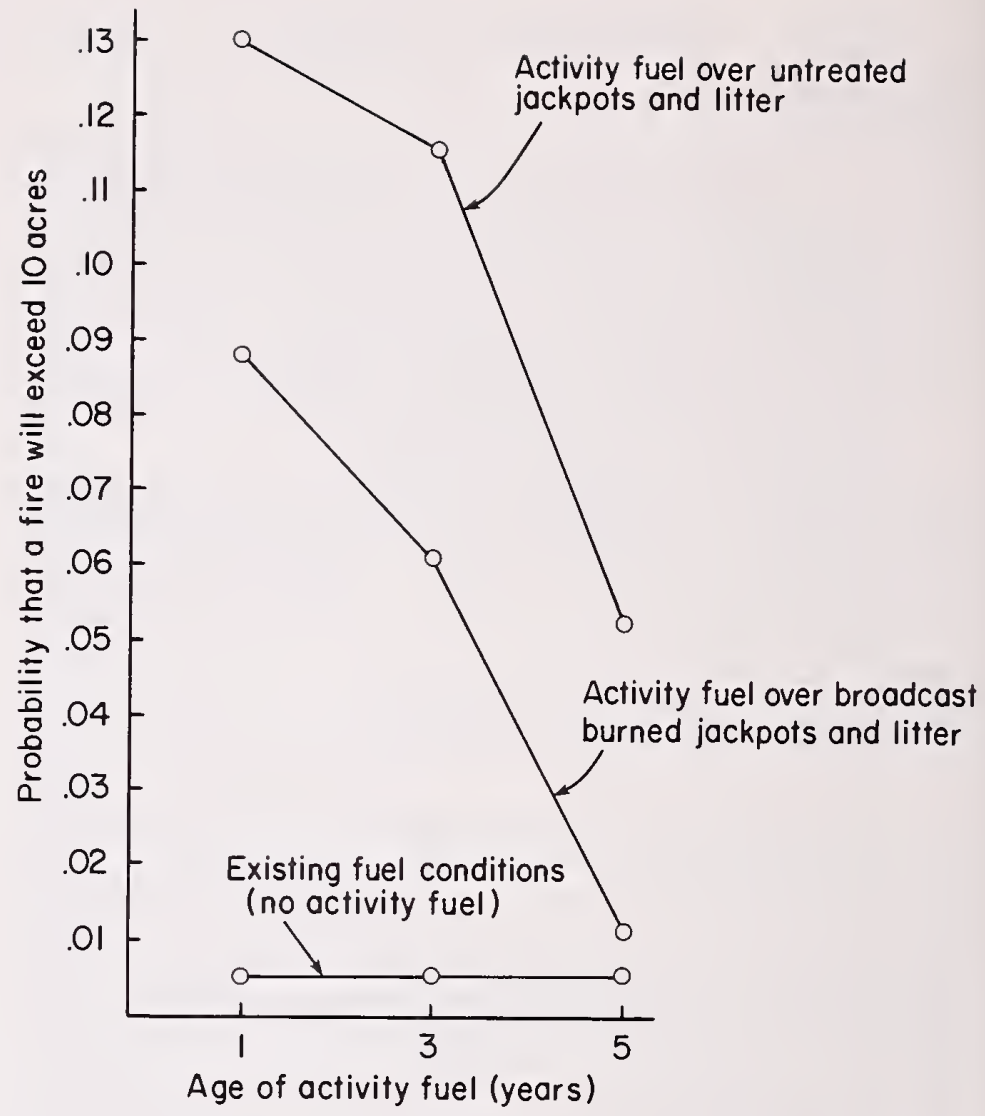

Figure 4.- Modeled large-fire probability under various fuel conditions. The decrease with time reflects the natural weathering of slash.

\section{Expected Acres Burned}

The expected annual burned acreage for each fuelbed (fig. 5) is the product of the annual number of ignitions, the probability an ignition will develop into a large fire, and the average size of a large fire. The Mormon Lake Ranger District fire occurrence rate of 1 fire per 3,500 acres per year indicates an expected occurrence rate of 3.4 fires annually for the 12,000-acre Woods Canyon area. Therefore, if no slash is present:

Expected
acres burned
per year

Expected burned acreage provides a means for comparing fuel treatment effectiveness.

\section{Economic Analysis}

One way to evaluate the alternative fuel treatments is by comparing their cash flows for the entire 12,000-acre area. To make this comparison, we need estimates of the value lost (or gained) because of fire and the value gained because of silvicultural treatments. The present net worth of the cash flow for each alternative will then reflect its economic merit. 


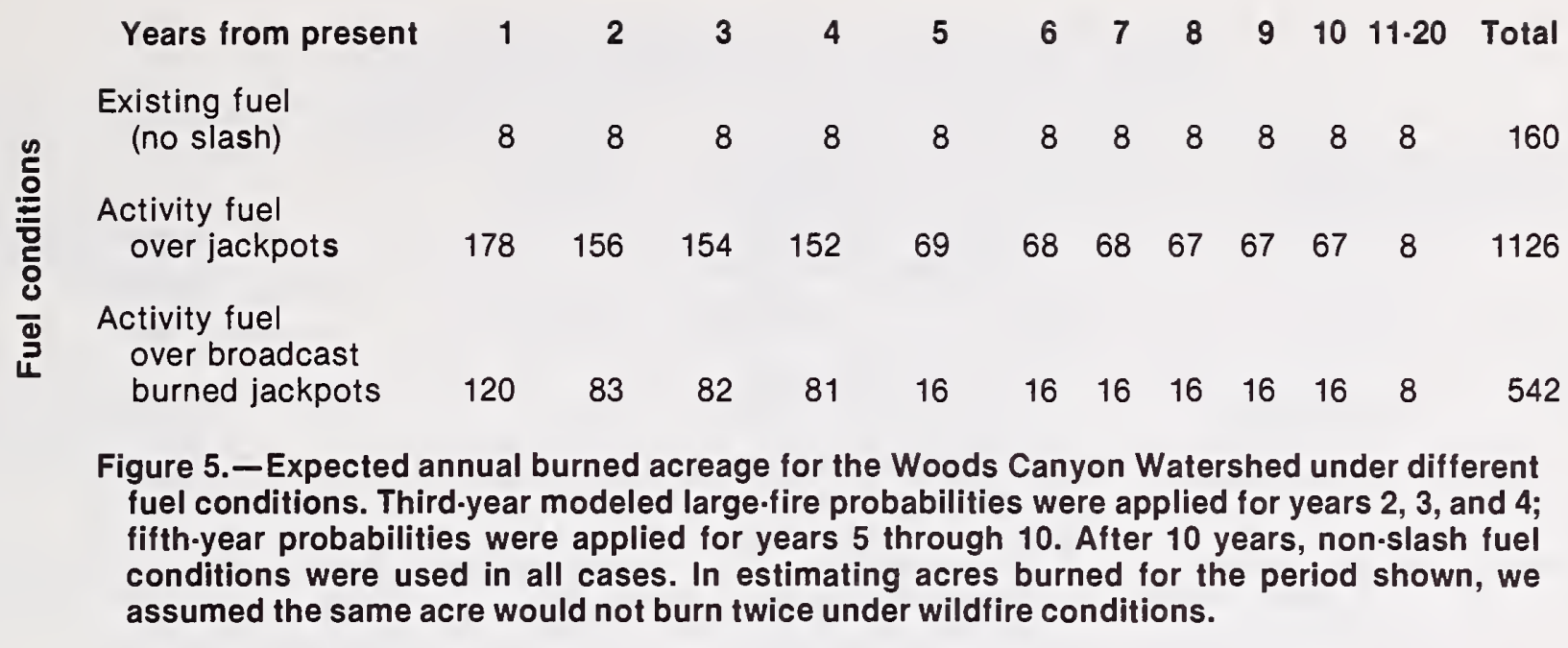

Evaluating the economic effect of a fire was simplified by considering only the effect on the timber resource. In the ponderosa pine type, fire damage is highly correlated with the number of acres which are intensely burned (Biswell et al. 1973). The large fire, burning with high intensity and often accompanied by crowning, causes most of the fire losses. For these fires, loss can be represented as the timber value per acre times the number of acres burned.

The sustainable timber harvest volume depends upon the silvicultural treatment applied and the number of acres which escape burning by high intensity fire. Under the proposed cutting regime for Woods Canyon (precommercial thinning, pulpwood thinning, and selection sawlog harvesting) the expected sustained harvest is 3,600 board feet per acre plus 3 cords per acre every 20 years. This represents a silvicultural optimum: any deviation will reduce timber production.

Table 1 describes the fuel models and activities associated with each fuel management alternative. The harvest volumes per acre in year 21 do not reflect fire losses. Actual dollar loss due to fire includes fire suppression costs and the value of the timber destroyed (we have assumed no salvage occurs). Based on past experience, the cost of suppressing fires larger than 10 acres is $\$ 500$ per acre. Lost timber value is reflected in a reduced area of mature timber available at the next harvest.

The unit costs and values used in the economic analysis are as follows:

Sawtimber stumpage at year 21 (assuming a $2 \%$ annual real value increase and $\$ 140$ present value)

$\$ 213 / \mathrm{Mfbm}$

Pulpwood stumpage at year 21 (assuming a $2 \%$ annual real value increase and $\$ 6$ present value) $\$ 9 /$ cord

Large fire suppression $\$ 500 /$ acre
Precommercial thin

$\$ 20 /$ acre

Prescribe burn for fuel reduction

$\$ 10 /$ acre

Prescribe burn for fuel reduction and thinning

$\$ 10 /$ acre

Machine pile and burn sawtimber slash \$28/acre

Machine pile and burn pulp slash

$\$ 28 /$ acre

Hand pile and burn precommercial thin slash

$\$ 42$ /acre

The cash flow over 21 years for the "treat only sawtimber slash" alternative is shown in figure 6 . In year 1 , the cost of machine piling and burning sawtimber slash is $\$ 336,000$ ( $\$ 28$ /acre $\mathrm{x} 12,000$ acres). There is also a $\$ 240,000$ precommercial thinning cost. First year timber revenues were excluded in order to evaluate present fuel treatments as investments in future stands. First year harvests would occur regardless of fuel treatments. In year 21, when the next cutting entry occurs, sawtimber revenue is $\$ 8,338,183$ (3.6 Mfbm/acre $\mathrm{x} \$ 213 / \mathrm{Mfbm} \times[12,000$ acres - 1,126 acres burned]) and pulpwood revenue is $\$ 293,598$ (3 cords/acre x $\$ 9 /$ cord $x$ [12,000 acres - 1,126 acres burned]). Each year there is a cost associated with fighting the expected large fires. The first year this cost is $\$ 89,000$ ( $\$ 500 /$ acre $\times 178$ acres). Cash flows for the other alternatives appear in appendix 3.

Table 2 is a comparison of the present net worth (at $5 \%$ interest rate) and expected acres burned for each fuel treatment alternative. The "treat only sawtimber slash" alternative results in the highest present net worth, but it also has by far the highest burned acreage. Through just one cutting period, more than $9 \%$ of the watershed is expected to burn. The large burned acreage would probably reduce the sustainable harvest volume/acre under this alternative. The effect on present net worth of such a reduction in harvest volume is illustrated in the following section on sensitivity analysis. 
Table 1.-Woods Canyon fuel management alternatives

\begin{tabular}{|c|c|c|c|c|}
\hline Alternative & Fuel model used & 1st year activities & 10th year activities & 21st year activities \\
\hline $\begin{array}{l}\text { Treat only sawtimber } \\
\text { slash }\end{array}$ & $\begin{array}{l}\text { Activity fuel over } \\
\text { jackpots }\end{array}$ & $\begin{array}{l}\text { Cut sawtimber and } \\
\text { pulpwood. Pile and } \\
\text { burn sawtimber slash. } \\
\text { Precommercial thin. }\end{array}$ & & $\begin{array}{l}\text { Cut } 3.6 \mathrm{Mfbm} / \mathrm{acre} \\
\text { sawtimber. Cut } \\
3 \text { cords/acre pulpwood. }\end{array}$ \\
\hline Treat all slash & $\begin{array}{l}\text { Existing fuel } \\
\text { condition }\end{array}$ & $\begin{array}{l}\text { Cut sawtimber and } \\
\text { pulpwood. Pile and } \\
\text { burn all slash. } \\
\text { Precommercial thin. }\end{array}$ & & $\begin{array}{l}\text { Cut } 3.6 \mathrm{Mfbm} / \mathrm{acre} \\
\text { sawtimber. Cut } \\
3 \text { cords/acre pulpwood. }\end{array}$ \\
\hline Broadcast burn & $\begin{array}{l}\text { Activity fuel } \\
\text { over broadcast } \\
\text { burned jackpots }\end{array}$ & $\begin{array}{l}\text { Cut sawtimber. }{ }^{1} \\
\text { Precommercial thin. } \\
\text { Broadcast burn prior } \\
\text { to cutting. Pile and } \\
\text { burn sawtimber slash. }\end{array}$ & $\begin{array}{l}\text { Prescribed maintenance } \\
\text { burn }\end{array}$ & Cut $2.4 \mathrm{Mfbm} / \mathrm{acre}{ }^{2}$ \\
\hline
\end{tabular}

'No pulpwood is harvested under the last two alternatives because char resulting from broadcast burning makes trees unacceptable to local mills.

${ }^{2}$ Firm numbers for these yields were not available. The 21-year yields for alternatives 3 and 4 reflect the assumption that intermediate cutting can increase the yield by up to $50 \%$ (from personal communication with Bob Alexander, Rocky Mountain Forest and Range Experiment Station, Fort Collins, Colorado).

${ }^{3}$ This fuel model represents a conservative model for the "thin with fire" alternative, in that it should over-estimate fire intensities. When thinning is done with fire, the killed trees become part of the fuelbed gradually over time. The model assumes a "slash" bed is created immediately. Therefore, expected loss figures for alternative 4 should represent upper bounds.

Year

$\begin{array}{lllll}1 & 2 & 3 & 4 & 5\end{array}$

$\begin{array}{lll}6 & 7 & 8\end{array}$

9

$1011 \ldots 20$

21

Sawtimber stumpage

Pulpwood stumpage

Machine pile and burn

sawtimber slash

Machine pile and burn

pulpwood slash

Precommercial thin $\quad-240$

Hand pile and burn

thinning slash

Broadcast burn

Suppression cost

$$
-89-78-77-76-34.5-34-34-33.5-33.5-33.5 \quad-4
$$

Total$$
-665-78-77-76-34.5-34-34-33.5-33.5-33.5-4
$$

Present net worth

$$
2,104.8
$$

Figure 6. -Twenty-one year cash flow for the "treat only sawtimber slash" alternative using a $5 \%$ interest rate. The values listed are in $\$ 1,000$ units. Costs and revenues were assumed to occur at the end of each year. 
Table 2.-Comparison of cash flows and acres burned for the fuel treatment alternatives over one cutting period (amounts in thousands of dollars)

\begin{tabular}{|c|c|c|c|c|}
\hline & $\begin{array}{l}\text { Treat all } \\
\text { slash }\end{array}$ & $\begin{array}{l}\text { Treat only } \\
\text { sawtimber } \\
\text { slash }\end{array}$ & $\begin{array}{l}\text { Broadcast burn } \\
\text { prior to } \\
\text { cutting }\end{array}$ & $\begin{array}{c}\text { Broadcast burn } \\
\text { to thin }\end{array}$ \\
\hline $\begin{array}{l}\text { Present value of } \\
\text { sawtimber }\end{array}$ & 3254 & 2989 & 2099 & 2099 \\
\hline $\begin{array}{l}\text { Present value of } \\
\text { pulpwood }\end{array}$ & 115 & 105 & 0 & 0 \\
\hline $\begin{array}{l}\text { Present value of } \\
\text { thinning costs }\end{array}$ & -229 & -229 & -229 & 0 \\
\hline $\begin{array}{l}\text { Present value of } \\
\text { fuel treatment costs }\end{array}$ & -1120 & -320 & -507 & -507 \\
\hline $\begin{array}{l}\text { Present value of } \\
\text { suppression costs }\end{array}$ & -50 & -445 & -216 & -216 \\
\hline $\begin{array}{l}\text { Present net worth } \\
\text { of alternative }\end{array}$ & 1975 & 2105 & 1150 & 1379 \\
\hline Acres burned & 160 & 1126 & 542 & 542 \\
\hline Percent area burned & 1.3 & 9.4 & 4.5 & 4.5 \\
\hline
\end{tabular}

The "total slash treatment" alternative shows the next highest present net worth. Since only 160 acres are expected to burn over a cutting period, this alternative would be best from a maximum wood production standpoint. There may also be associated with this alternative social values not reflected in the cash flow presented here. The large fuel treatment expenditure may be justified if the near-exclusion of large wildfires is a management goal.

The "broadcast burn before cutting" alternatives have the lowest present net worth values, although they become more favorable at higher interest rates (see sensitivity analysis). These alternatives would also be more favorable if a detailed stand growth/fire model were evaluated over a time frame longer than 21 years. There is strong evidence that the reintroduction of fire into the ponderosa pine forest community would reduce wildfire hazard over the long run (Biswell et al. 1973). Under a regime of periodic prescribed burning, wildfires would be less intense and more manageable. Broadcast burning after thinning might be a feasible fuel treatment alternative in this case, but it was not analyzed in this study.

\section{Sensitivity Analysis}

The preceding discussion accurately compares the alternatives if all assumptions and model outputs are correct. Since this may not be true, it is instructive to examine the effect on present net worth of varying the critical parameters over a reasonable range. The results of this sensitivity analysis are shown in figures 7 through 11 .

\section{Variations in Interest Rate}

The relative rankings of the "total slash treatment" and the two "broadcast burn" alternatives are quite sensitive to interest rate (fig. 7). At 9\% interest rate, the "broadcast burn to thin" alternative becomes second in ranking in terms of present net worth.

\section{Variations in Acres Burned}

All of the possible errors in fire modeling affect the predicted number of acres burned. Figure 8 shows the effect of uncertainty in this parameter. If the true burned acreage is one-half of the predicted values shown in figure 5 , the ranking of alternatives is unchanged. However, if the true acreage is 1.2 to 2 times the predicted amounts, the "total slash treatment" alternative is favored.

\section{Variations in Sapling Stand Density}

Figure 9 shows that if the density of sapling stands exceeds about 1,500 stems per acre, the "total slash treatment" alternative has the highest present net worth. 


\section{Variations in Sustainable Harvest Volumes}

As indicated earlier, the sustainable harvest volumes under several of the alternatives are uncertain. Figures 10 and 11 show the effects of this uncertainty. If the future harvest volume under the "treat only sawtimber slash" alternative is actually less than $95 \%$ of our assumed value due to the effects of the large burned acreage, the "total slash treatment" becomes the first choice. If the harvest volume for the "broadcast burn" alternatives are higher than our conservative estimate of 2.4 Mfbm/acre, these two alternatives become much more favorable and may even be preferred in terms of present net worth. Since the selection of an alternative is so sensitive to this parameter, more study is warranted concerning the relationship between broadcast burning to thin stands, hand thinning, wildfire damage, and timber yield.

\section{Summary}

A complete analysis of fuel treatments must ultimately involve economic consideration of the effects of fuel treatment on fire hazard, timber production, wildlife habitat, soil characteristics, water yield and quality, and recreation values. A major obstacle

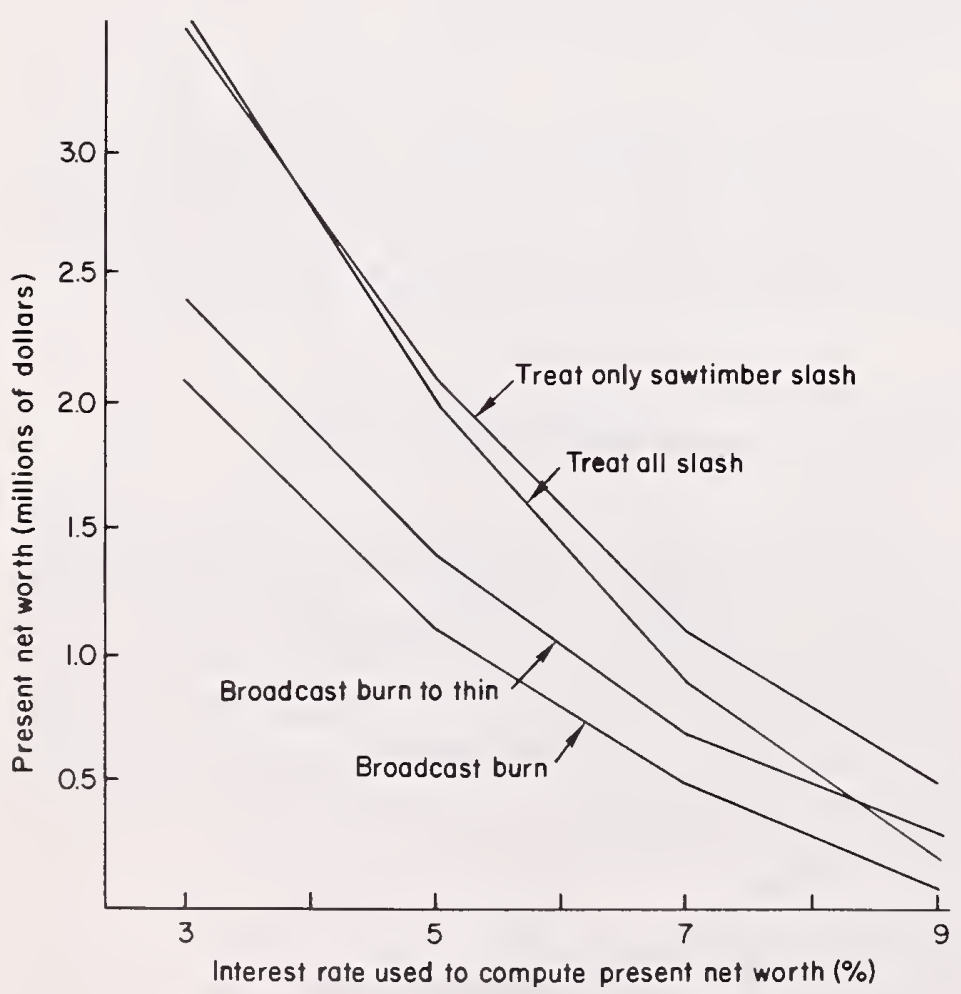

Figure 7.-Sensitivity of present net worth to variations in interest rate.

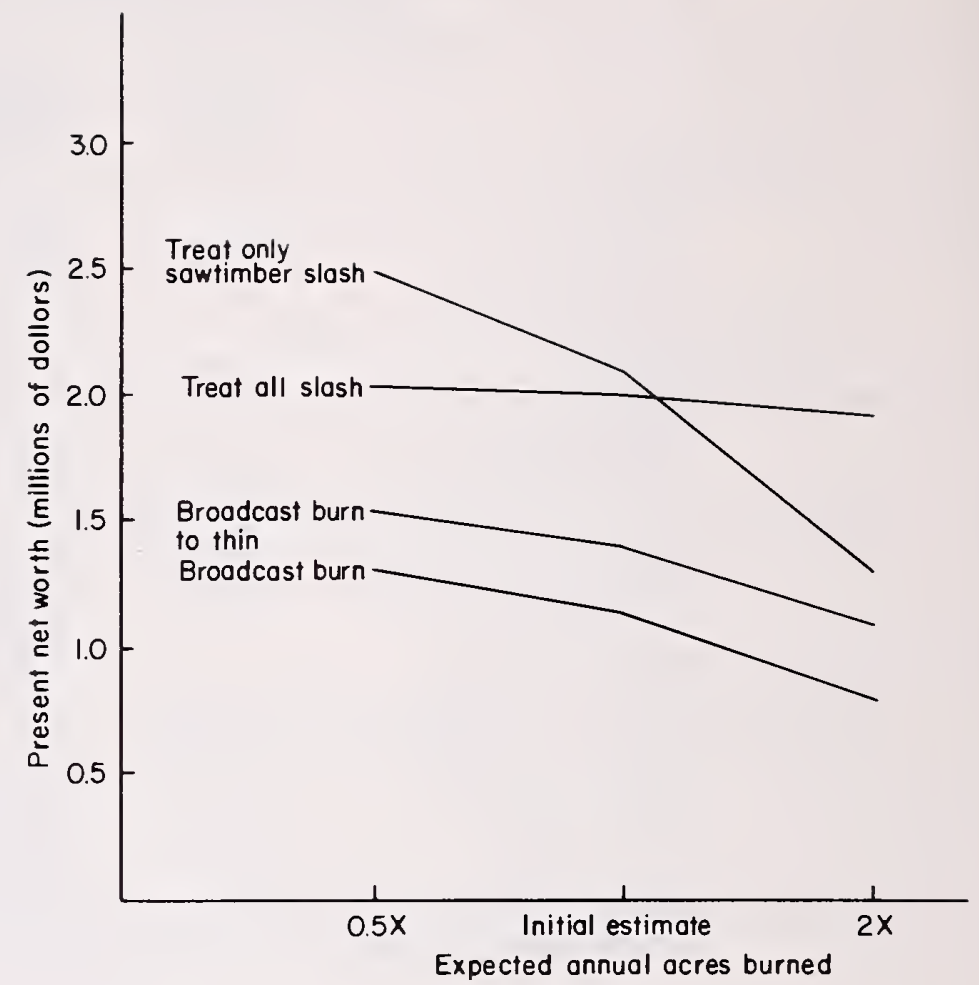

Figure 8.- Sensitivity of present net worth (at $5 \%$ interest rate) to variations in expected annual acres burned for all alternatives.

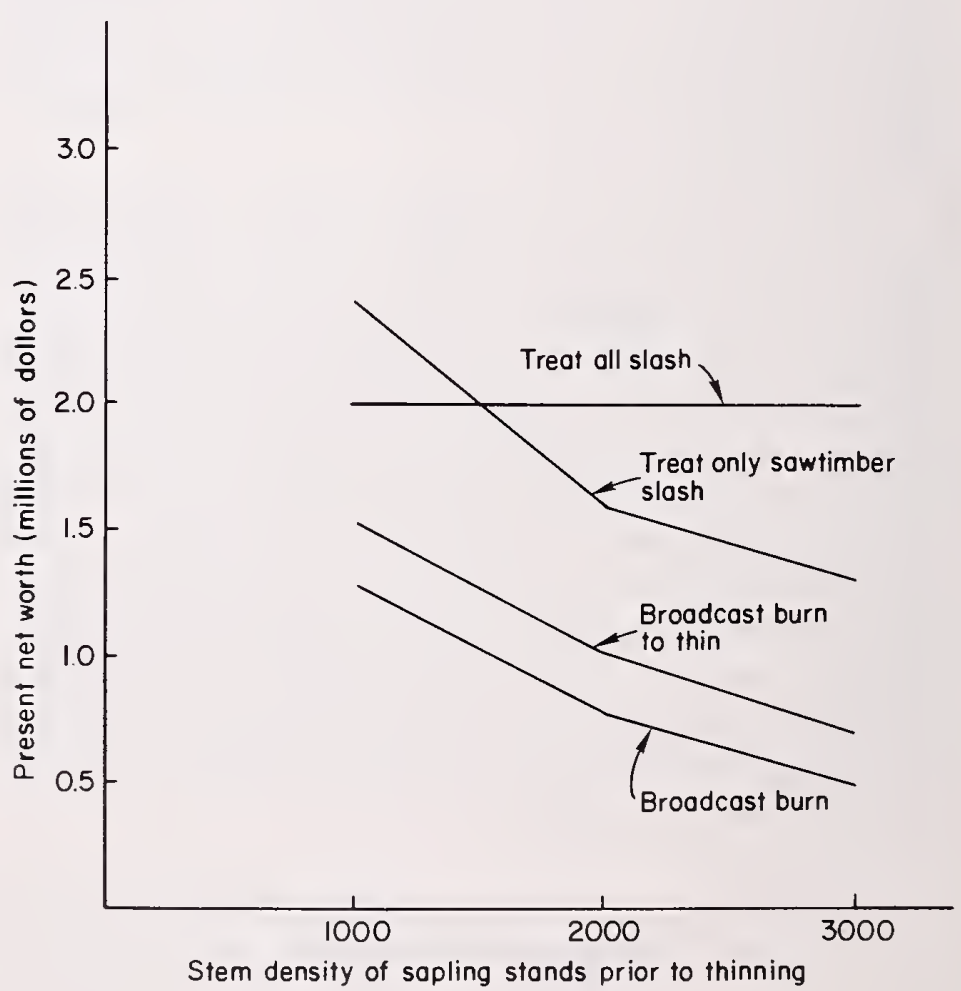

Figure 9.- Sensitivity of present net worth (at 5\% interest rate) to variations in sapling stem density prior to thinning. Our initial estimate of average stem density is about 1,400 stems per acre. 
has been the lack of a quantitative procedure for incorporating the fire hazard considerations. This case study describes an analytic procedure combining decision analysis, fire behavior modeling, and fuelbed modeling which provides the necessary fire hazard inputs. Fire hazard is described in terms of expected acres burned annually. The next step is to describe the effects of various fire regimes on resource production functions and operational costs.

For the Woods Canyon case study, only the effects on the timber resource are described. The economic analysis, using a $5 \%$ interest rate, indicates the minimum fuel treatment alternative (treat only sawtimber slash) appears to be preferred. As the sensitivity analysis indicates incorporating better timber production information or incorporating more resource values could change the selection of a fuel treatment. This reflects the fact that any decision can only be as good as the information used in the decision process.

The procedure outlined provides managers with the best available information concerning the fire hazard aspects of fuel treatments, and it clearly documents the factors involved in reaching a final decision.

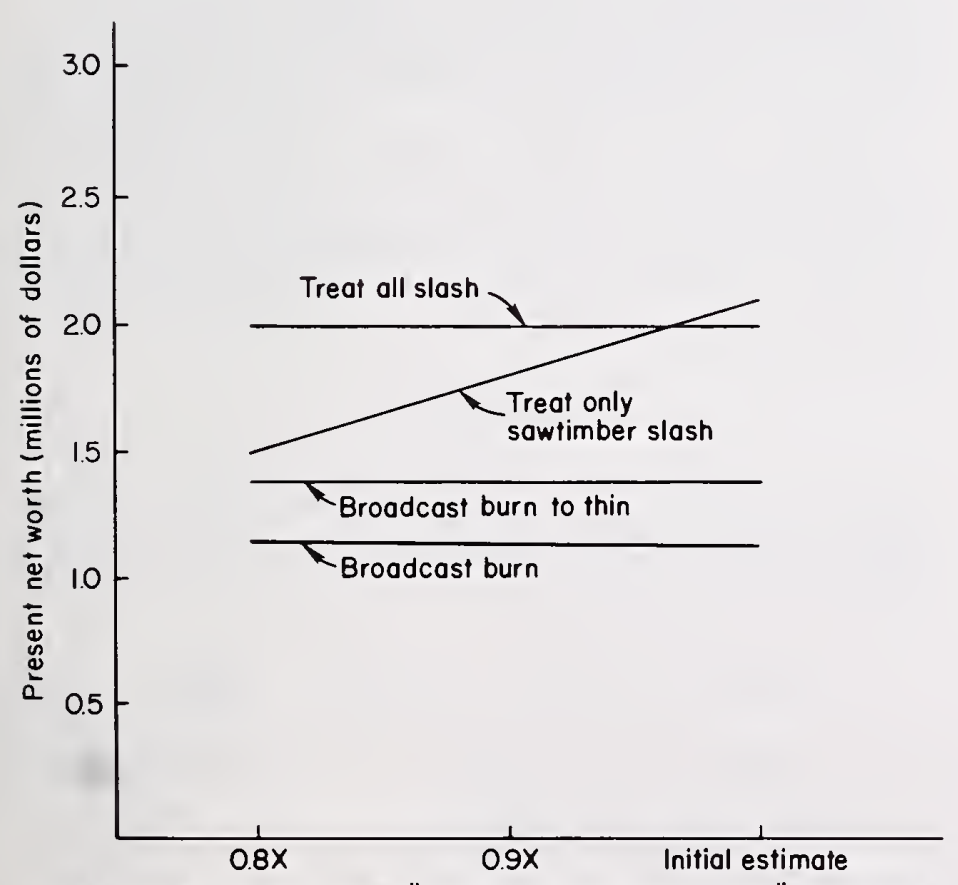

Future timber harvest under "freat only sawtimber slash" alternative

Figure 10.-Sensitivity of present net worth (at $5 \%$ interest rate) to variations in future sawtimber and pulpwood harvest volumes under the "treat only sawtimber slash" alternative where the initial estimate equals $3.6 \mathrm{Mfbm}$ sawtimber and three cords pulpwood.

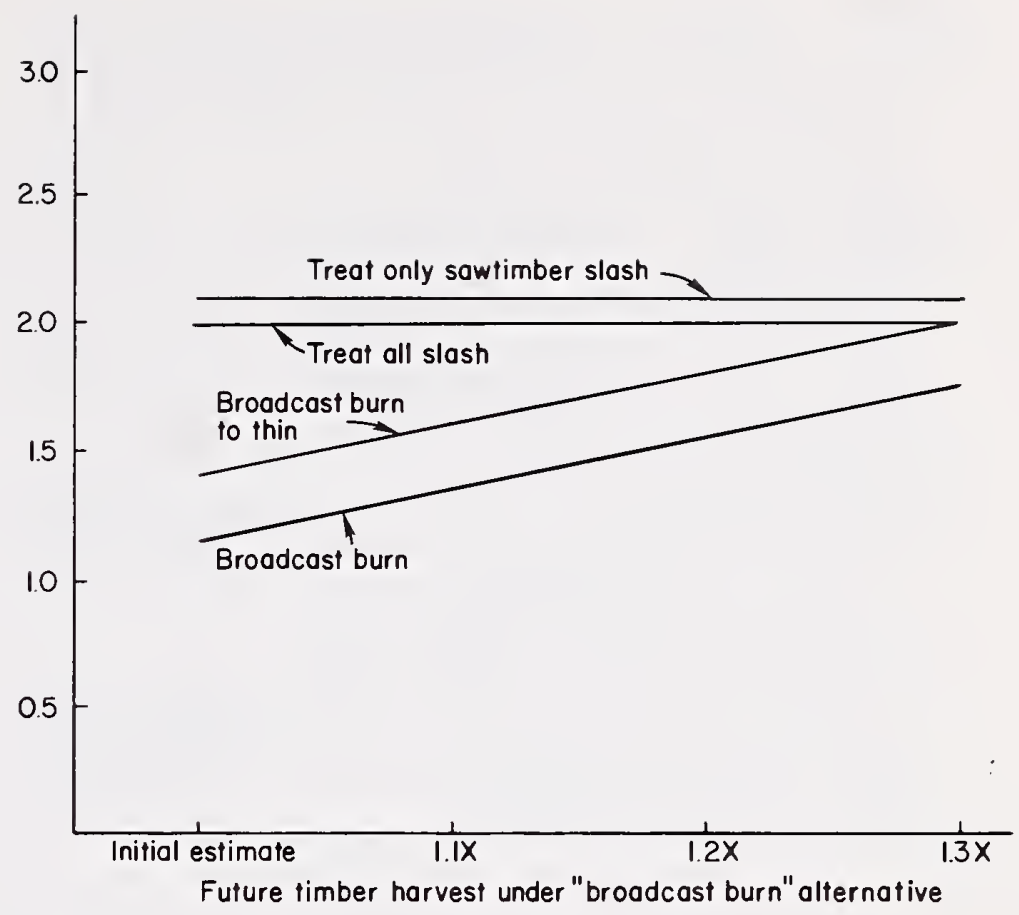

Figure 11.-Sensitivity of present net worth (at $5 \%$ interest rate) to variations in future sawtimber harvest volumes under the "broadcast burn" alternatives where the initial estimate equals $2.4 \mathrm{Mfbm}$ sawtimber.

\section{Literature Cited}

Albini, Frank A. 1976a. Estimating wildfire behavior and effects. USDA For. Serv. Gen. Tech. Rep. INT-30, 92 p. Intermt. For. and Range Exp. Stn., Ogden, Utah.

Albini, Frank A. 1976b. Computer-based models of wildland fire behavior: A user's manual. 68 p. U.S. Dep. Agric., For. Serv., Intermt. For. and Range Exp. Stn., Ogden, Utah.

Albini, Frank A., and James K. Brown. 1978. Predicting slash depth for fire modeling. USDA For. Serv. Res. Pap INT-206, 22 p. Intermt. For. and Range Exp. Stn., Ogden, Utah.

Biswell, Harold H., Harry R. Kallander, Roy Komarek, Richard J. Vogl, and Harold Weaver. 1973. Ponderosa fire management: A task force evaluation of controlled burning in ponderosa pine forests of central Arizona. Misc. Publ. 2, 49 p. Tall Timbers Res. Stn., Tallahassee, Fla.

Brown, James K., J. A. Kendall Snell, and David L. Bunnell. 1977. Handbook for predicting slash weight of western conifers. USDA For. Serv. Gen. Tech. Rep. INT-37, 35 p. Intermt. For. and Range Exp. Stn., Ogden, Utah.

Davis, James R., Peter F. Ffolliott, and Warren P. Clary. 1968. A fire prescription for consuming ponderosa pine duff. USDA For. Serv. Res. Note RM-115, 4 p. Rocky Mt. For. and Range Exp. Stn., Fort Collins, Colo. 
Ffolliott, Peter F., Warren P. Clary, and James R. Davis. 1968. Some characteristics of the forest floor under ponderosa pine in Arizona. USDA For. Serv. Res. Note RM-127, 4 p. Rocky Mt. For. and Range Exp. Stn., Fort Collins, Colo.

Puckett, John V., Cameron M. Johnston, Frank A. Albini, James K. Brown, David L. Bunnell, William C. Fischer, and J. A. Kendall Snell. 1979. Users' guide to debris prediction and hazard appraisal. 37 p. U.S. Dep. Agric., For. Serv., North Reg., Missoula, Mont.

Rothermel, Richard C. 1972. A mathematical model for predicting fire spread in wildland fuels. USDA For. Serv. Res. Pap. INT-115, 40 p. Intermt. For. and Range Exp. Stn., Ogden, Utah.

U.S. Department of Agriculture, Forest Service. 1977. The Beaver Creek program: Advancing forest and range resource management. 23 p. Washington, D.C.

\section{Appendix 1 \\ Large-Fire Spotting Model}

The spotting model is based on the assumption that a surface fire will not spot unless it reaches a jackpot within a doghair clump of trees. We need to estimate the probability an initial fire reaches that point before suppression forces arrive. The assumption is made that if initial suppression forces arrive prior to torching, the fire will be contained at less than 10 acres. The chance of continuous spotting is dependent upon six factors:

1. Fire spread rate in the litter.

2. Density of doghair clumps which contain fuel concentrations (jackpots).

3. The lag time following ignition of a jackpot before torching occurs.

4. Time required for suppression forces to attack the initiating fire and spot fires.

5. Number of firebrands produced when a doghair stand torches out.

6. Probability that a firebrand causes an ignition.

\section{Fire Spread Rate in Litter}

Rothermel's fire behavior model (Rothermel 1972, Albini 1976a, 1976b) provides a method to estimate litter fire spread rates. Slope and wind strongly influence fire spread. We used zero percent as a representative slope. To estimate the wind near the combustion zone at the surface, we used one-fourth of the reported 20 -foot wind measurement. The model assumes a fire is heading with the wind. Figure A1 shows the distribution of fire spread rates which were predicted for a litter fire based on fire-conditional weather data recorded at Flagstaff.

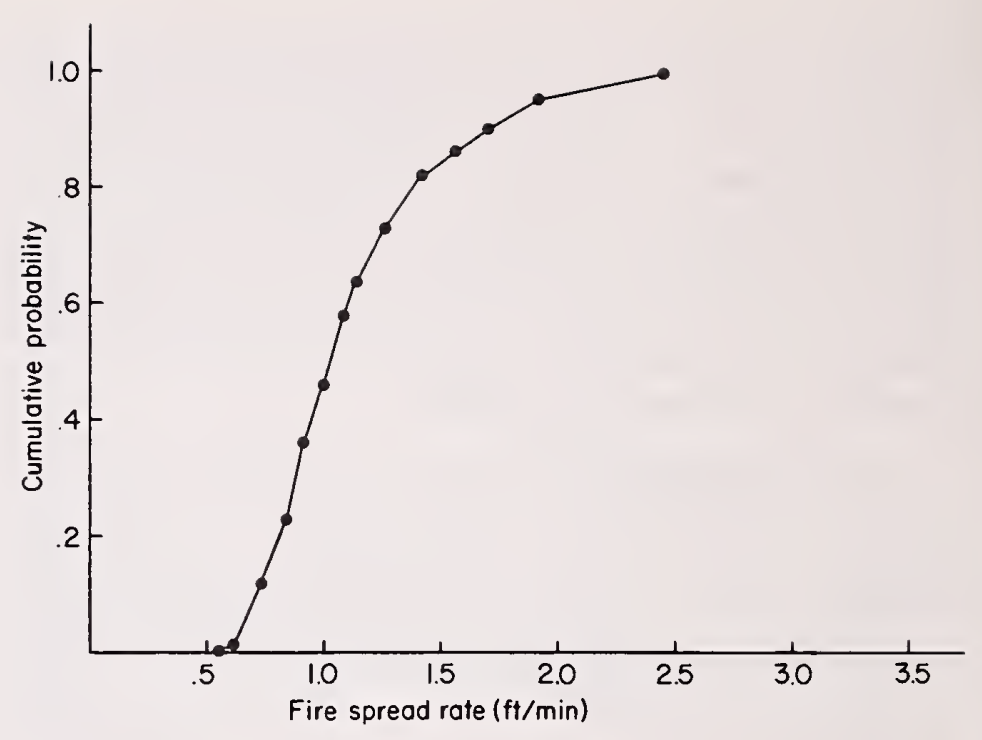

Figure A1. - Cumulative probability distribution of litter fire spread rates. The distribution was generated by executing the fire behavior model for daily fire-conditional weather conditions. Weather records were selected for days on which fires have occurred on the Mormon Lake Ranger District.

\section{Density of Doghair Clumps}

Line transect inventories were made to provide information about doghair stand and jackpot distributions. A straight line was walked through a sample area with the following data being recorded:

1. Total distance traveled (D).

2. Distance traveled through doghair stands (d).

3. Number of doghair stands $(\mathrm{N})$.

4. Number of doghair stands with jackpots (n).

Assuming that doghair clumps are circular, the average distance traveled through a clump, $d / N$, is $\pi / 4$ times the average clump diameter (the expected length of a cord of a circle is $\pi / 4$ times the diameter of the circle), $\bar{w}$, or

$$
\overline{\mathrm{w}}=\frac{4}{\pi} \times \frac{\mathrm{d}}{\mathrm{N}}
$$

This average diameter represents the width of an imaginary belt transect used to sample clump density. The total area sampled is $\overline{\mathrm{w}} * \mathrm{D}$, so

$$
\text { Density of doghair clumps }(\lambda)=\frac{n}{\bar{w} \times D}
$$

For the Woods Canyon area, the estimated density is 1.3 doghair clumps per acre.

\section{Lag Time}

The lag time between ignition of a jackpot and initiation of torching varies with changes in fuel configuration and fuel moisture. Personal observations indicate 10 minutes is a reasonable time. 


\section{Attack Time}

Forest Service fire records include time elapsed from report of fire to the attack. Fire reports were used to determine the historical distribution of attack times for initial fires on the Mormon Lake Ranger District. Since attacking a long-range spot fire is similar to attacking an initially reported fire, the same distribution was used for attack times on spot fires. The distribution of attack times for fires on the Mormon Lake District is shown in figure A2.

\section{Firebrand Production and Ignition Probability}

When torching occurs and firebrands are produced, the number of spot fires is the product of two variables:

$$
\begin{aligned}
& \text { Number of long-range spot fires }=\text { (number } \\
& \text { of firebrands) } \mathrm{x} \text { (probability a } \\
& \text { firebrand causes ignition) }
\end{aligned}
$$

The probability a firebrand will cause an ignition is a function of fine fuel moisture and temperature, ${ }^{5}$ but the number of firebrands is unknown. This situation prompted the assumption that when spotting occurs, only one new, completely independent fire is generated.

Assuming a random distribution of jackpots in the forest, the Poisson probability that a fire has reached $j$ jackpots is:

${ }^{5}$ National Interagency Fire Center. 1977. Fire behavior affects control operations. Included in National interagency fire training course S-590-Fire behavior officer school, Marana, Ariz.

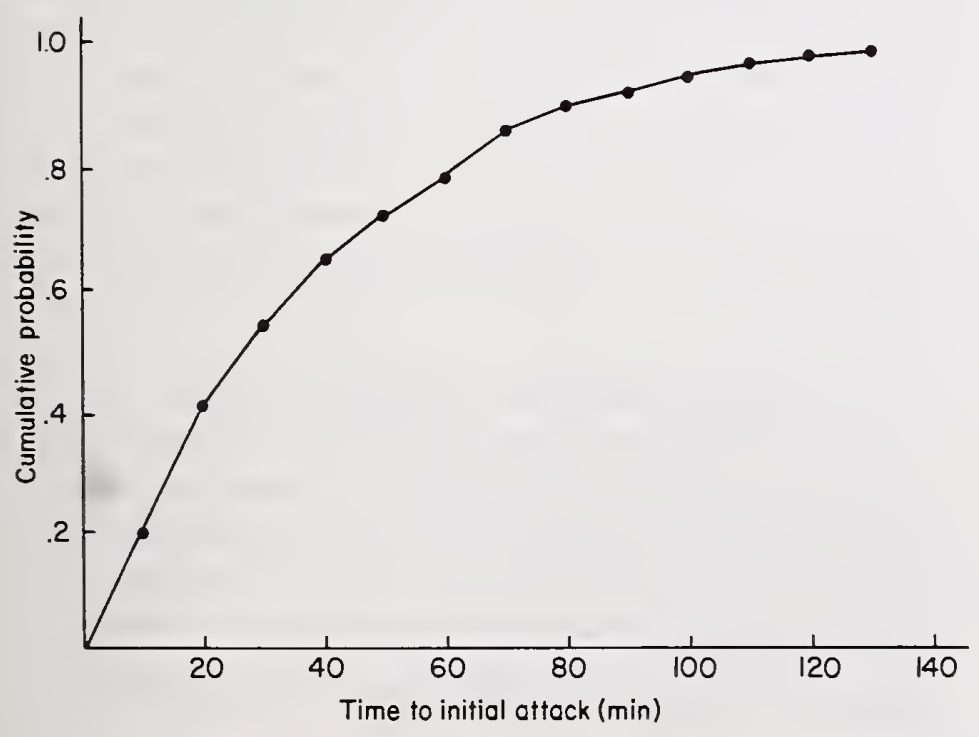

Figure A2.-Cumulative probability distribution of initial attack times for fires on the Mormon Lake Ranger District.

$$
P\{j\}=\frac{\left(\pi r^{2} \lambda\right)^{j} e^{-\left(\pi r^{2} \lambda\right)}}{j !}
$$

where

$\mathrm{j}=$ number of jackpots within the fire's perimeter

$\lambda=$ density of jackpots (number/square foot)

$r=$ radius of fire (feet)

The probability that no jackpot $(\mathrm{j}=0)$ has been reached by a fire is:

$$
P\{0\}=e^{-\left(\pi r^{2} \lambda\right)}
$$

Alternatively,

$$
P\{0, t\}=e^{-\left(\pi v^{2} t^{2} \lambda\right)}
$$

where

$$
\begin{aligned}
\mathrm{P}\{0, \mathrm{t}\}= & \text { probability that no jackpots have } \\
& \text { been reached after } \mathrm{t} \text { minutes of } \\
& \text { fire spread. } \\
\mathrm{v}= & \text { fire spread rate (feet/minute) } \\
\mathrm{t}= & \text { time since ignition (minutes) }
\end{aligned}
$$

Since the jackpot density, $\lambda$, is 1.3 jackpots/acre or $2.984 \cdot 10^{-5} \mathrm{jackpot} / \mathrm{ft}^{2}$,

$$
P\{0, t\}=e^{-9.375 \cdot 10^{-5} \mathrm{v}^{2} \mathrm{t}^{2}}
$$

The cumulative distribution of attack times in figure A2 can be expressed as:

$$
\int_{0}^{t} P\{\text { attack at time } t\} d t=1-e^{-.030 t}
$$

The corresponding density function for attack time is:

$$
\mathrm{P}\{\mathrm{a}\}=\mathrm{P}\{\text { attack at time } \mathrm{t}\}=.030 \mathrm{e}^{-.030 \mathrm{t}}
$$

We can use equations [7] and [9] to express the probability that a fire will be controlled before torching occures ( $\mathrm{P}\{$ control\}). Recall that 10 minutes pass from the time a fire reaches a jackpot until tree crowns begin to torch out.

$$
\begin{aligned}
& P\{\text { control }\}=\int_{0}^{10} P_{a}\{t\} d t+\int_{10}^{\infty} P_{a}\{t\} P\{0, t-10\} d t \\
& =\int_{0}^{10} .030 e^{-.030 t} d t+ \\
& \int_{10}^{\infty} .030 e^{-.030 t} e^{-9.375 \cdot 10^{-5} \mathrm{v}^{2}(t-10)^{2}} d t
\end{aligned}
$$




$$
\begin{aligned}
& =0.26+ \\
& \int_{10}^{\infty} .030 e^{-.030 t} e^{-9.375 \cdot 10^{-5} v^{2}(t-10)^{2}} d t
\end{aligned}
$$

$$
\text { By letting } \mathrm{u}=\mathrm{t}-10 \text {, }
$$$$
\mathrm{P}\{\text { control }\}=0.26+
$$$$
\int_{0}^{\infty} .030 \mathrm{e}^{-.030(\mathrm{u}+10)} \mathrm{e}^{-9.375 \cdot 10^{-5} \mathrm{v}^{2} \mathrm{u}^{2}} \mathrm{du}
$$

$$
=0.26+.022 \int_{0}^{\infty} e^{-9.375 \cdot 10^{-5} v^{2} u^{2}-.030 u} d u
$$

The integration in equation [14] was performed numerically for the three values of $\mathrm{v}$ in the event tree of figure 2. The results are as shown in table A1. Probability of spotting is 1.0 minus the probability of control before spotting. As indicated earlier, two spotting events in sequence is the condition for an escaped fire which will become larger than 10 acres. The chance of this joint occurence is:

\section{$\mathrm{P}\{$ sequential spotting $\}=\mathrm{P}\{$ spotting $\} \times \mathrm{P}\{$ spotting $\}[15]$}

For the case when thinning slash is present, the probability of sequential spotting, given that weather conditions are right for spotting, is:

$$
\begin{gathered}
\mathrm{P}\{\text { sequential spotting }\}=\mathrm{P}\{\text { fire reaches } \\
\text { slash before control }\} \\
\mathrm{x} \mathrm{P}\{\text { slash fireline intensity } \geqslant 700 \mathrm{Btu} / \mathrm{ft}-\mathrm{sec}\} \\
\mathrm{x} \mathrm{P}\{\text { new fire reaches slash before control }\}
\end{gathered}
$$

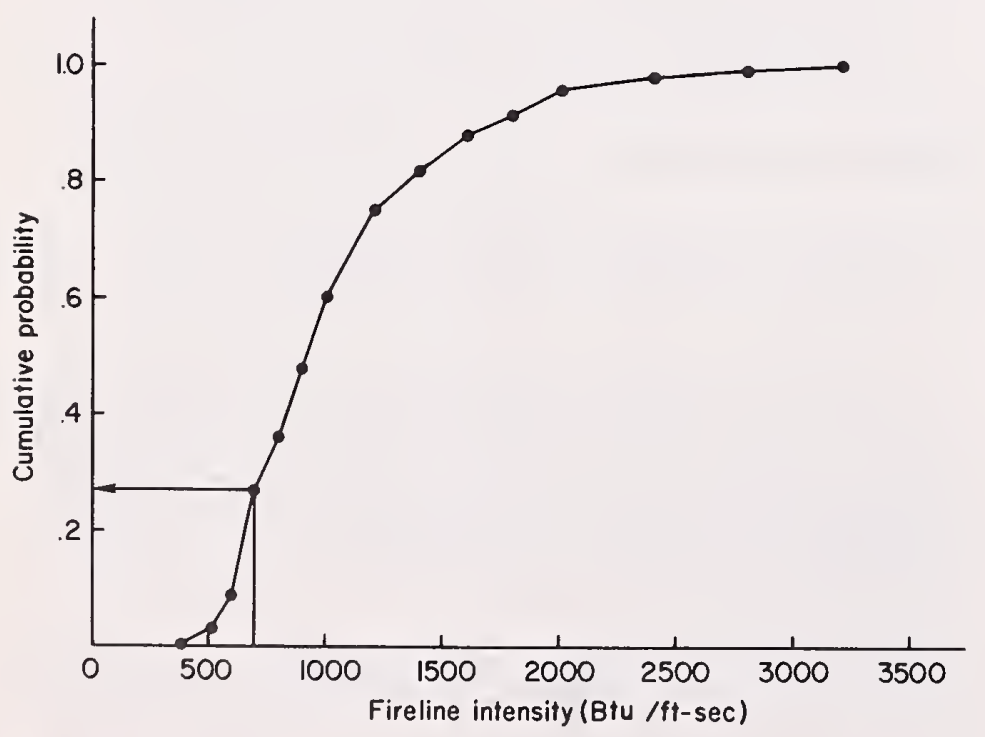

Figure A3. - Cumulative probability distribution of modeled fireline intensity for fires in activity fuel. The fuelbed results from thinning a 1,000 stem/acre sapling stand which contains sound.log jackpots. This graph shows there is a 0.73 probability that fire will burn with a fireline intensity exceeding $700 \mathrm{Btu} / \mathrm{ft}$-sec.
Table A1._Probability of sequential spotting

\begin{tabular}{cccc}
\hline $\begin{array}{c}\text { Spread rate } \\
\text { (v) }\end{array}$ & $\begin{array}{c}\text { P\{control before } \\
\text { spotting\} }\end{array}$ & P\{spotting\} & $\begin{array}{c}\text { P\{sequential } \\
\text { spotting\} }\end{array}$ \\
\hline (ft/min) & & & \\
0.83 & 0.910 & 0.090 & 0.0081 \\
1.21 & 0.837 & 0.163 & 0.0266 \\
1.76 & 0.785 & 0.215 & 0.0462 \\
\hline
\end{tabular}

The probability that the slash fireline intensity exceeds $700 \mathrm{Btu} / \mathrm{ft}$-sec was determined from cumulative probability curves, such as the example in figure A3, for each fuelbed condition.

The probability that a fire reaches slash before control is achieved was estimated by a procedure analogous to the determination of the probability of spotting in the "no slash" case discussed above. The probability is 0.83 that any fire will reach some slash before being controlled.

For the fuelbed situation represented in figure A3, then

$$
\begin{aligned}
& \mathrm{P}\{\text { sequential spotting }\}= \\
& 0.83 \times 0.73 \times 0.83=0.50
\end{aligned}
$$

This number is entered as the topmost "sequential spotting" probability in the event tree in figure 3.

\section{Appendix 2 \\ Fuel Models}

Fire behavior was modeled for one litter and two slash fuel situations. The fuel models are shown in table $\mathrm{A} 2$ and are discussed below.

1. Existing fuel conditions (litter).-This represents the fuel prior to harvesting. The true needle load can easily range from less than 1 to more than 3 tons per acre. Two tons per acre was selected as a representative load. ${ }^{6}$ Fire growth rate estimates from this model were used in the analysis of both the preharvest conditions and the "treat all slash" alternative.

2. Activity fuel over jackpots. - This model represents the worst untreated slash fuel conditions. Fire behavior in the slash was modeled for activity fuels draped across existing jackpots. Because modeled fire intensities in precommercial thinning slash usually equal or exceed those in pulpwood slash, only the precommercial thinning cases were used for input to the decision trees. This avoids

${ }^{6}$ Personal communication with Steve Sackett, Research Forester, Rocky Mountain Forest and Range Experiment Station, Research Work Unit in Tempe, Ariz. 
Table A2. - Natural fuel particle loads for the fuel models used for estimating fire behavior. The quantities of additional slash fuel for the last two models are shown in table A3

\begin{tabular}{|c|c|c|c|}
\hline Fuel model & Particle size & \multicolumn{2}{|l|}{ Loading } \\
\hline & (inches) & (tons/acre) & \\
\hline $\begin{array}{l}\text { Existing fuel } \\
\text { (litter) }\end{array}$ & $\begin{array}{l}\text { Needles } \\
0 \text { to } 1 / 4 \\
1 / 4 \text { to } 1\end{array}$ & $\begin{array}{r}2.0 \\
10.2 \\
1.0\end{array}$ & \\
\hline $\begin{array}{l}\text { Activity fuel } \\
\text { over jackpots }\end{array}$ & $\begin{array}{l}\text { Needles } \\
0 \text { to } 1 / 4 \\
1 / 4 \text { to } 1 \\
1 \text { to } 3 \\
3+\text { sound } \\
3+\text { rotten } \\
\text { Plus slash fuel }\end{array}$ & $\begin{array}{c}2.0 \\
0.2 \\
1.0 \\
3.7 \\
\text { Elevates fuelbed } \\
\text { Elevates fuelbed }\end{array}$ & $\begin{array}{r} \\
19 \text { in } \\
9 \text { in }\end{array}$ \\
\hline $\begin{array}{l}\text { Activity fuel over } \\
\text { broadcast burned } \\
\text { jackpots }\end{array}$ & $\begin{array}{l}\text { Needles } \\
0 \text { to } 1 / 4 \\
1 / 4 \text { to } 1 \\
1 \text { to } 3 \\
3+\text { sound } \\
3+\text { rotten } \\
\text { Plus slash fuel }\end{array}$ & $\begin{array}{c}{ }^{3} 1.5 \\
0.02 \\
0.10 \\
0.93 \\
\text { Elevates fuelbed } \\
\text { Elevates fuelbed }\end{array}$ & $\begin{array}{l}5 \text { in } \\
5 \text { in }\end{array}$ \\
\hline
\end{tabular}

'All loads for 0- to 1/4-, 1/4- to 1-, and 1- to 3-inch woody fuels are based on data for Fort Valley Experimental Forest collected by John H. Dieterich and Steve Sackett. The average 1-to 3-inch load was increased to account for clumpiness in this size category.

${ }^{2}$ The elevating effect of jackpots is based on diameter measurements of more than 3-inch fuels at Fort Valley by Dieterich and Sackett. Sixty percent of all jackpots encountered were rotten; $40 \%$ were sound. We tripled the effective diameter of sound logs to reflect the fact that most sound jackpots still have branches intact.

${ }^{3}$ These figures are consistent with personal observations and prescribed burning results by Dieterich and Sackett. Davis et al. (1968) discuss increased needle accumulation following prescribed burning.

underestimating the large fire probability, since an initial ground fire may spread into both pulpwood and doghair slash. Estimation of slash amounts is discussed later in this appendix.

3. Activity fuel over broadcast burned jackpots. - This models the situation in which slash is created on top of existing fuels which have been prescribe burned. The slash is not treated. The model is used for the broadcast burning treatments.

Estimates of slash fuel quantities were based on stand analysis data ${ }^{7}$ and individual tree weight tables (Brown et al. 1977). The stand tables represent average stem densities for rather heterogeneous areas, so the average densities for 2- and 4-inch trees (saplings) do not reflect the clumpiness which actually exists. To estimate the density within doghair clumps, we multiplied the average number of 2- and 4-inch stems per acre by $1 / 0.15$, because sapling stands occupy about $15 \%$ of the Woods Canyon watershed.

Applying this factor results in the frequencies below:

'Unpublished data from Fred Larson, Research Forester, Rocky Mountain Forest and Range Experiment Station, Research Work Unit in Flagstaff, Ariz.
Density class interval

$$
\begin{gathered}
\text { (stems/acre) } \\
0-1500 \\
1500-2500 \\
2500-3500 \\
3500-4500 \\
4500+
\end{gathered}
$$

Relative frequency of occurrence

$$
\begin{aligned}
& 0.70 \\
& 0.20 \\
& 0.08 \\
& 0.01 \\
& 0.01
\end{aligned}
$$

Table A3 shows the calculation of slash loads for the five stocking classes. Thinning leaves 440 stems per acre (a 10- x 10-ft spacing). The distribution between diameter classes (before and after thinning) is $53 \%$ in 2-inch and $47 \%$ in the 4 -inch d.b.h. class.

\section{Appendix 3 \\ Cash Flows for the \\ Fuel Management Alternatives}

Figures A4, A5, and A6 show the cash flows which characterize three of the fuel treatment alternatives. The cash flow for the "treat only sawtimber slash" alternative is shown in figure 6. A 5\% interest rate was used in determining present net worth, and all costs and revenues were assumed to occur at the end of the appropriate year. Values in the figures are in thousands of dollars. 
Table A3.-Estimation of activity fuel loadings. Activity fuel (slash) loads were computed from tree crown weight tables developed by Brown et al. (1977). The first four columns in this table include data from stand tables and thinning prescriptions. The fifth and sixth columns contain individual tree crown weight data. Tons/acre of slash (last two columns) are computed as the product of stems per acre cut and pounds per tree, divided by 2,000

\begin{tabular}{|c|c|c|c|c|c|c|c|}
\hline \multirow{3}{*}{$\begin{array}{c}\begin{array}{c}\text { Density } \\
\text { class }\end{array} \\
1000\end{array}$} & \multirow{3}{*}{$\begin{array}{c}\begin{array}{c}\text { Diameter } \\
\text { class }\end{array} \\
2 \\
4\end{array}$} & \multirow{3}{*}{$\begin{array}{c}\begin{array}{c}\text { Stems/ } \\
\text { acre }\end{array} \\
530 \\
470\end{array}$} & \multirow{3}{*}{$\begin{array}{c}\begin{array}{c}\text { Stems } \\
\text { acre cut }\end{array} \\
297 \\
263\end{array}$} & \multirow{2}{*}{\multicolumn{2}{|c|}{$\begin{array}{c}\text { Pounds/tree }{ }^{1} \\
<3 \text { in }>3 \text { in }\end{array}$}} & \multirow{2}{*}{\multicolumn{2}{|c|}{$\begin{array}{l}\text { Tons/acre slash } \\
<3 \text { in }>3 \text { in }\end{array}$}} \\
\hline & & & & & & & \\
\hline & & & & $\begin{array}{l}7.05 \\
23.8\end{array}$ & $\begin{array}{l}0.70 \\
12.0\end{array}$ & $\begin{array}{l}1.1 \\
3.1\end{array}$ & $\begin{array}{l}0.10 \\
1.60\end{array}$ \\
\hline 2000 & $\begin{array}{l}2 \\
4\end{array}$ & $\begin{array}{r}1060 \\
940\end{array}$ & $\begin{array}{l}827 \\
733\end{array}$ & $\begin{array}{l}7.05 \\
23.8\end{array}$ & $\begin{array}{l}0.70 \\
12.0\end{array}$ & $\begin{array}{l}2.9 \\
8.7\end{array}$ & $\begin{array}{r}0.29 \\
4.4\end{array}$ \\
\hline 3000 & $\begin{array}{l}2 \\
4\end{array}$ & $\begin{array}{l}1590 \\
1410\end{array}$ & $\begin{array}{l}1357 \\
1203\end{array}$ & $\begin{array}{l}7.05 \\
23.8\end{array}$ & $\begin{array}{l}0.70 \\
12.0\end{array}$ & $\begin{array}{r}4.8 \\
14.3\end{array}$ & $\begin{array}{r}0.47 \\
7.2\end{array}$ \\
\hline 4000 & $\begin{array}{l}2 \\
4\end{array}$ & $\begin{array}{l}2120 \\
1880\end{array}$ & $\begin{array}{l}1887 \\
1673\end{array}$ & $\begin{array}{l}7.05 \\
23.8\end{array}$ & $\begin{array}{l}0.70 \\
12.0\end{array}$ & $\begin{array}{l}6.65 \\
12.0\end{array}$ & $\begin{array}{r}0.66 \\
10.04\end{array}$ \\
\hline 5000 & $\begin{array}{l}2 \\
4\end{array}$ & $\begin{array}{l}2650 \\
2350\end{array}$ & $\begin{array}{l}2417 \\
2143\end{array}$ & $\begin{array}{l}7.05 \\
23.8\end{array}$ & $\begin{array}{l}0.70 \\
12.0\end{array}$ & $\begin{array}{r}8.52 \\
25.50\end{array}$ & $\begin{array}{r}0.85 \\
12.86\end{array}$ \\
\hline
\end{tabular}

1 In determining tree weights by the method of Brown, Snell, and Bunnell, we assumed all the 2 -inch stems and $60 \%$ of the 4-inch stems were classified as suppressed or intermediate.

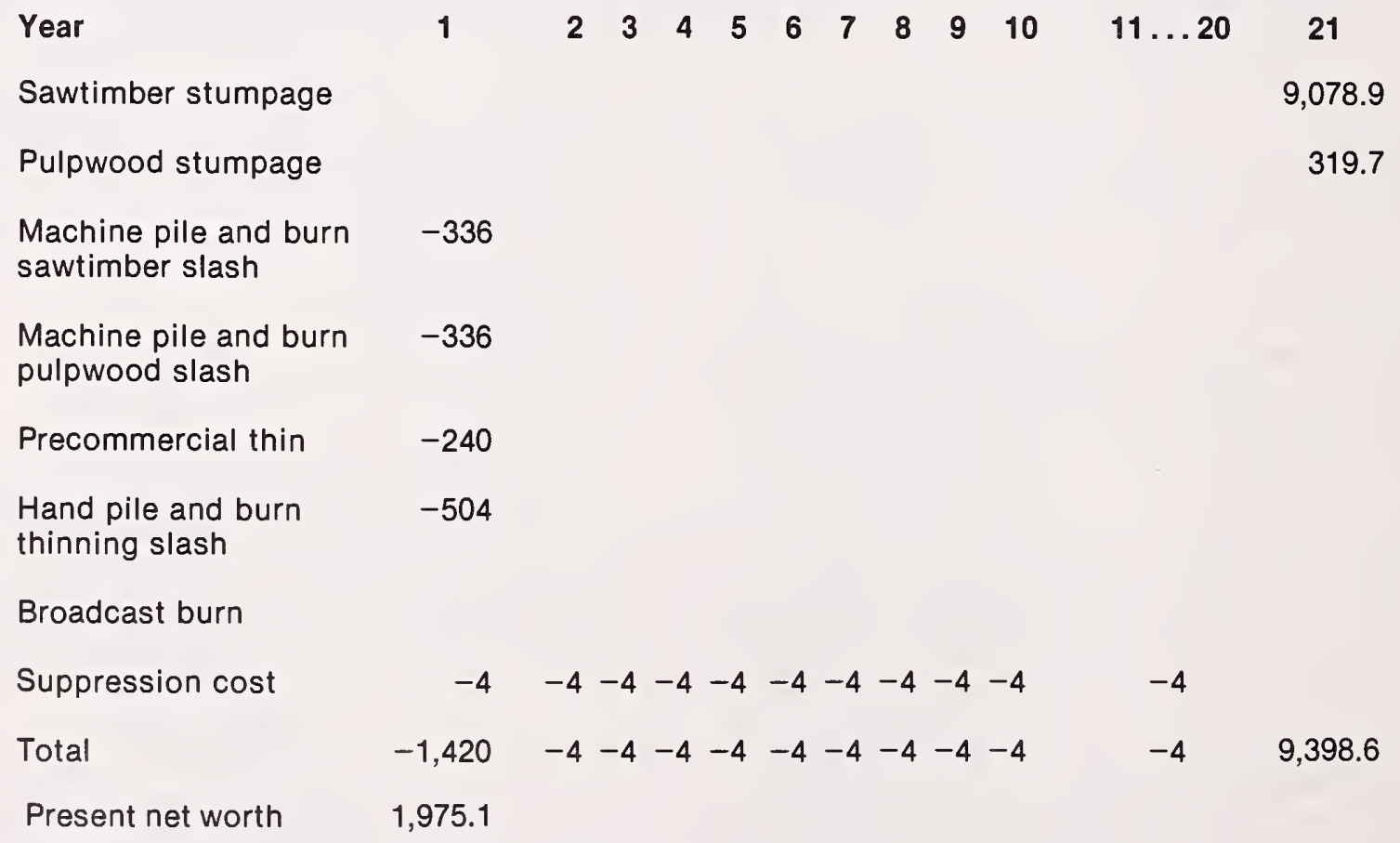

Figure A4. - Cash flow (dollars/acre) for the "treat all slash" alternative showing expected timber revenues, treatment costs, and suppression costs for a 21 -year projection. 
Sawtimber stumpage

Pulpwood stumpage

Machine pile and burn

sawtimber slash

Machine pile and burn

pulpwood slash

Precommercial thin $\quad-240$

Hand pile and burn

thinning slash

Broadcast burn

Suppression cost

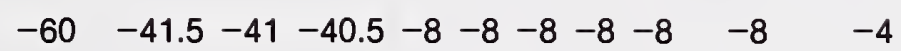

Total

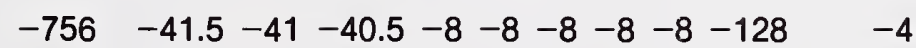

Present net worth $\quad 1,150.0$

Figure A5.-Cash flow for the "broadcast burn before cutting" alternative.

Year

$$
123
$$

Sawtimber stumpage

Pulpwood stumpage

Machine pile and burn sawtimber slash

Machine pile and burn pulpwood slash

Precommercial thin

Hand pile and burn

thinning slash

Broadcast burn

Suppression cost

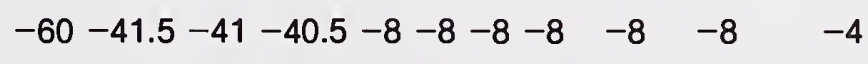

Total $-516-41.5-41-40.5-8-8-8-8 \quad-8-128 \quad-4$

Present net worth $1,378.6$

Figure A6. - Cash flow for the "broadcast burn to thin" alternative. 


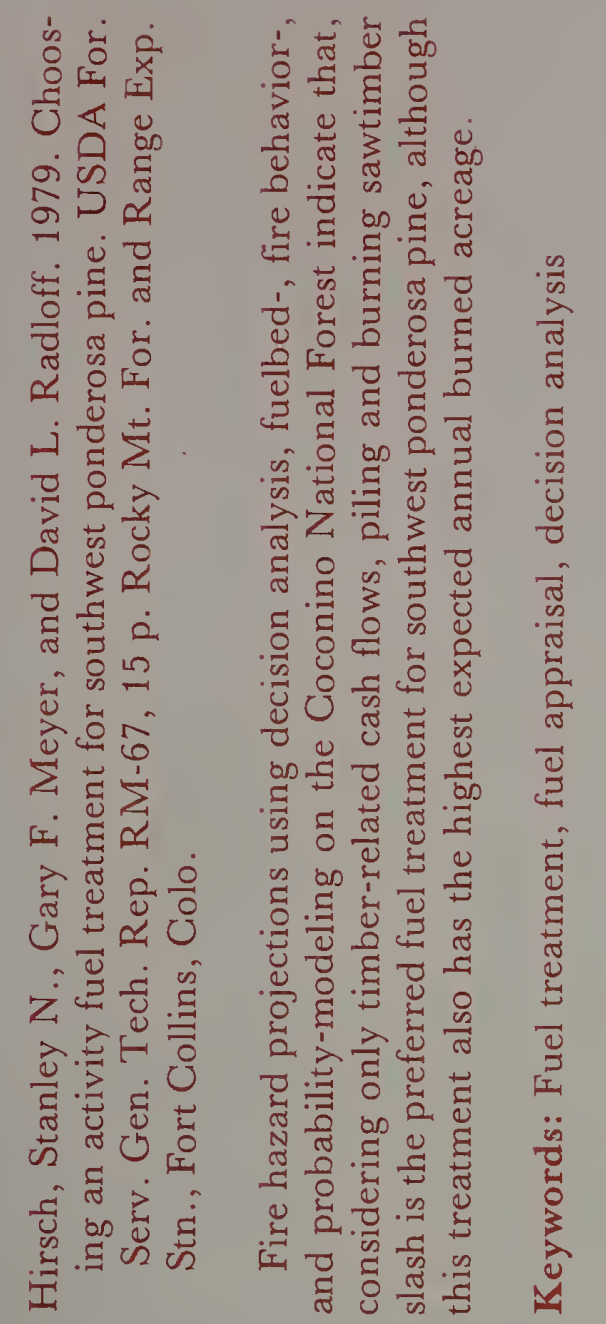

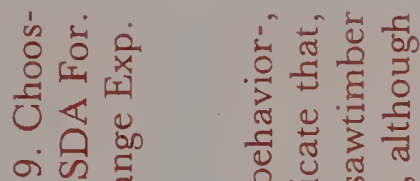

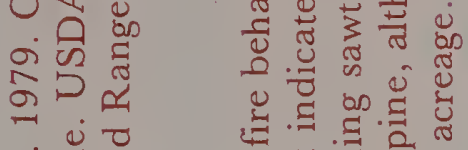

世्य

चี ॠ

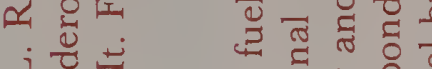

듈

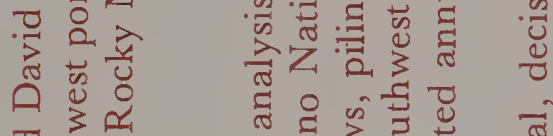

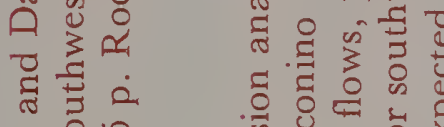

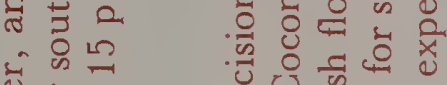

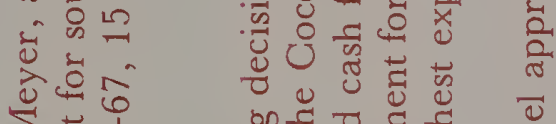

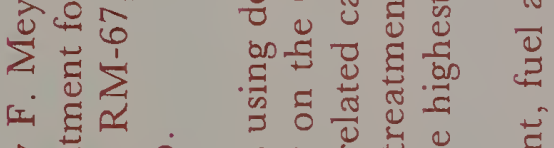

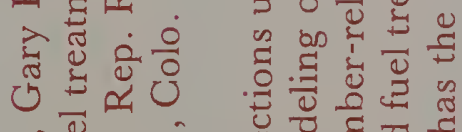

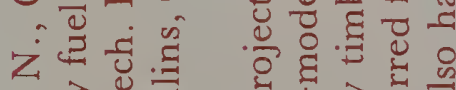

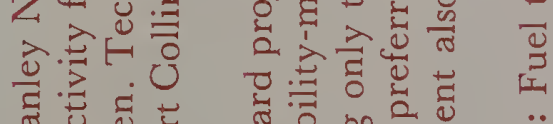

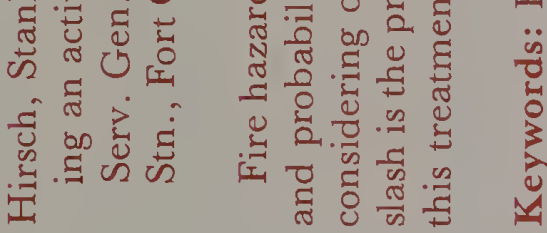
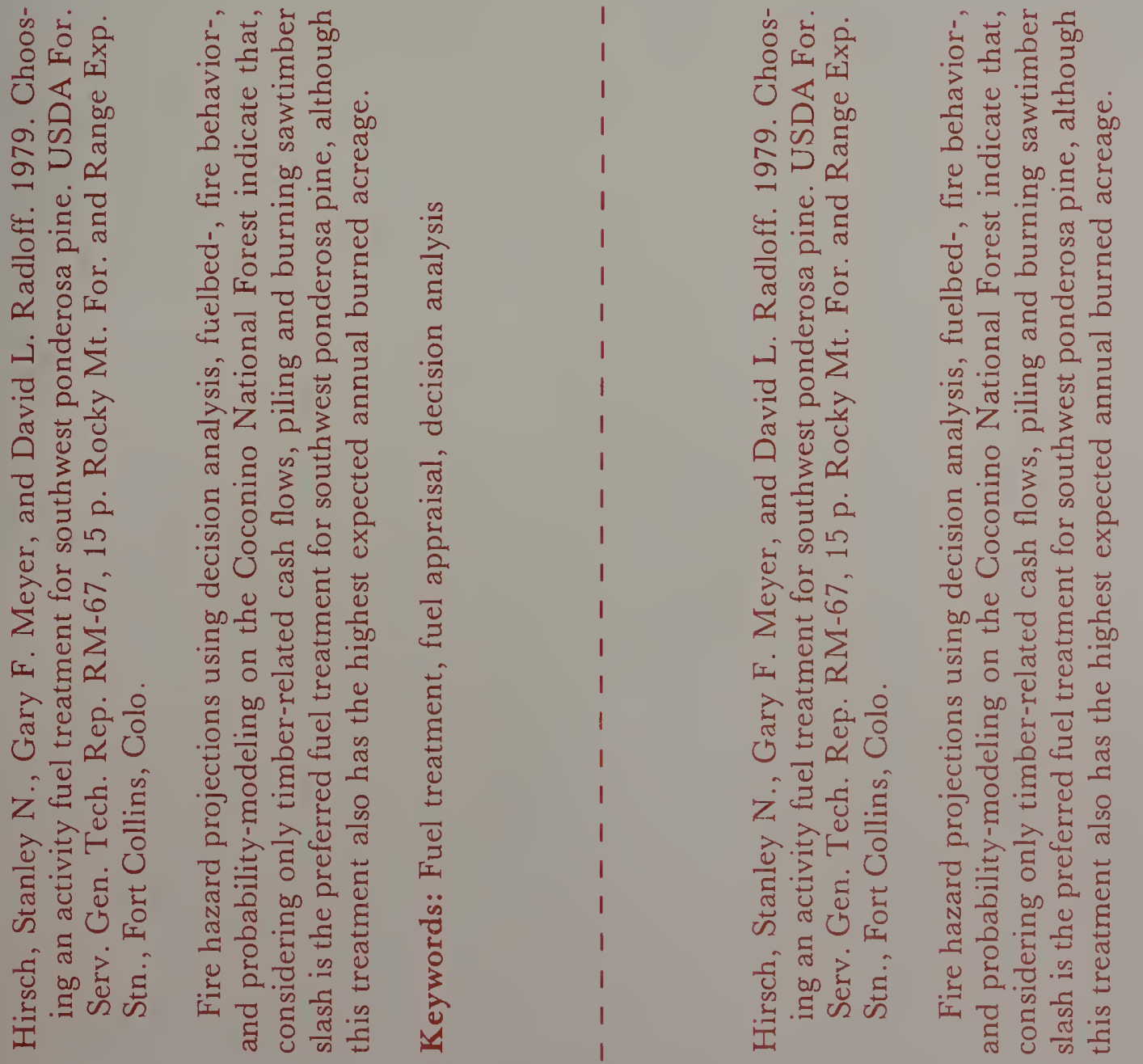

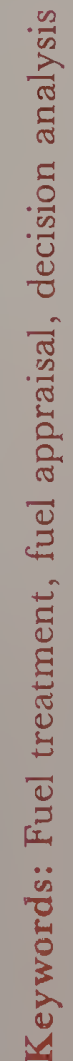




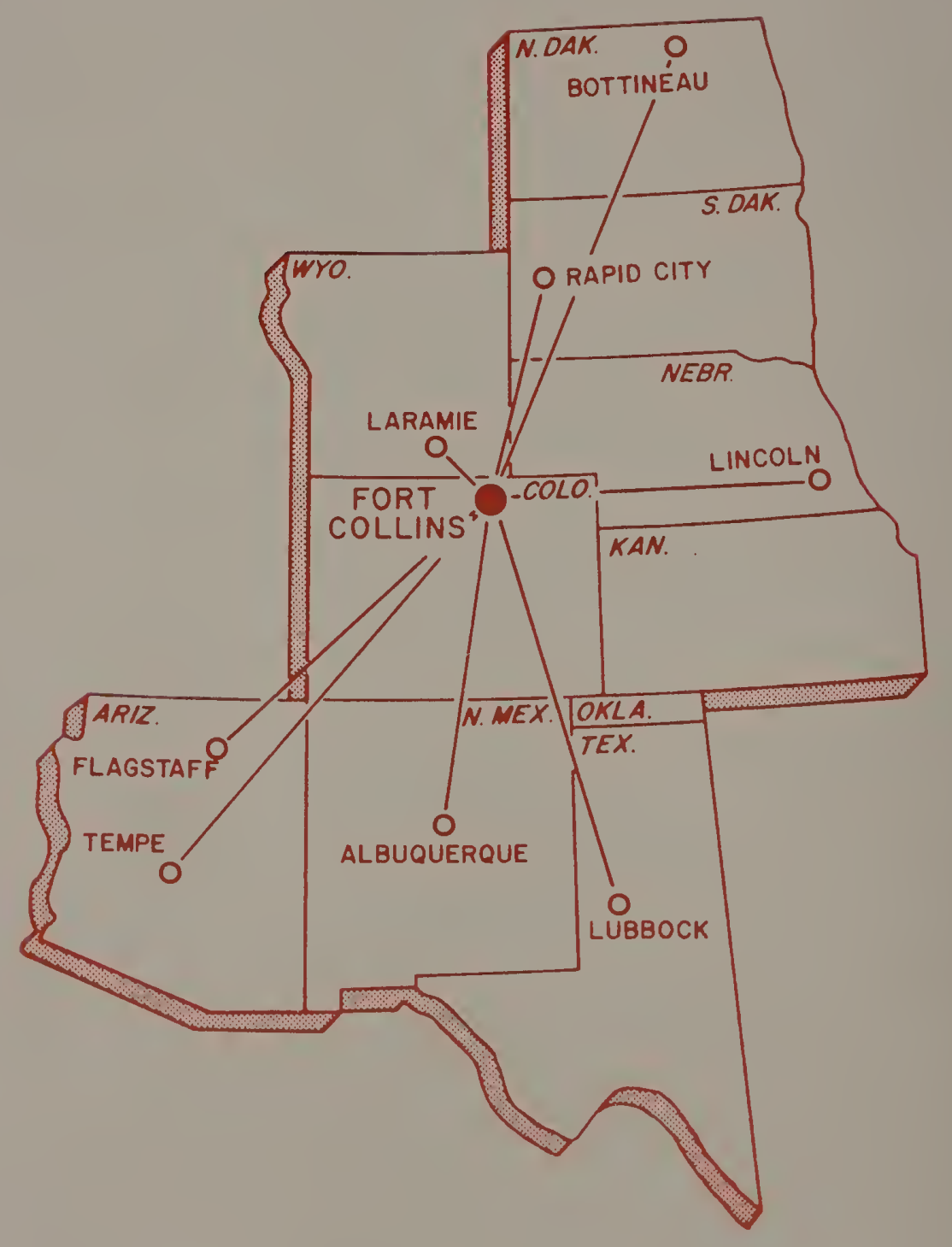

